\title{
Analysing the heavy goods vehicle "écotaxe" in France: Why did a promising idea fail in implementation?
}

\author{
Patrick Rigot-Müller \\ Maynooth University, School of Business, Maynooth, Co. Kildare, Ireland
}

\section{A R T I C L E I N F O}

\section{Keywords:}

Road tax acceptance

Transport policy

Freight transport

Green taxation

Greater Paris

\begin{abstract}
A B S T R A C T
In October 2014, France abandoned the implementation of the écotaxe, a major country-wide Electronic Tolling System (ETS) designed to charge for the use of national and local roads, which were not covered by the traditional toll system. The écotaxe originated from a political consensus and was designed with the collaboration of business stakeholders. However, unforeseen implementation difficulties resulted in a renouncement at a late stage, when the infrastructure was already deployed. According to a recent report from the French body in charge of auditing public expenses, it generated a cost of 953 million euros. In analysing what happened during the policy delivery stage, this paper provides insights to policymakers in countries where ETS is envisaged.

The ETS system was piloted in summer 2013, and the "go live" date was 1st September 2014. Data was collected 'live', in March 2014, featuring 21 interviews, with the aim of better understanding the expected challenges and impacts on the business stakeholders. At the time, stakeholders accepted that the project would go ahead: while further implementation challenges remained, few anticipated them to fully derail the project within 6 months. Retrospective analysis of the data collected in March 2014 can help to deepen policymakers' insights into why the project ultimately failed and better understand the main lessons to be learnt. The findings show that the écotaxe, presented as environmental taxation by policymakers, had been in reality perceived and accepted by business stakeholders as more of an infrastructure tax. Interestingly, this in itself does not explain the failure. The main explanation is to be found in the perceived inequities associated with the charging approach, excluding privately-operated motorways, and the failure of the ad valorem surcharging system designed as a means of passing the tax costs to shippers. These findings should be valuable for policymakers anywhere the introduction of a similar ETS system is being contemplated.
\end{abstract}

\section{Introduction}

This paper analyses the attempted implementation of an Electronic Toll System (ETS) for Heavy Goods Vehicles (HGV) in France. The political impetus for this system, "Ecotaxe Poids Lourds" (called "écotaxe" hereafter) followed the "Grenelle de l'environnement", held in 2007, a nation-wide forum and agreements on environmental issues (Ollivier-Trigalo, 2013). The system was inspired by the "LKW-Maut", the ETS for HGV implemented on German motorways in 2005. A major difference however, was that while German motorways were free of charge prior to the LKW-Maut implementation, most French motorways were already tolled. The écotaxe was an attempt to extend road taxation in France to secondary roads that remained untaxed at the time.

The implementation of the écotaxe had multiple delays. The principle of an écotaxe was first approved by parliament in

E-mail address: patrick.rigotmuller@mu.ie. 
September 2008, and written into law in 2009. It should have entered into force at the latest on the 31 st of December 2011 (Assemblée Nationale, 2008, p. 134; Journal Officiel, 2009). In April 2010 it was postponed to 2012 (Harnay, 2012). In October 2011 it was further postponed to mid-2013 (Assemblée Nationale, 2011, p. 32). In May 2012 the principle of an ad valorem surcharging system to shippers was written into law, but no starting date was mentioned (Journal Officiel, 2012). In January 2013, another starting date was announced: July 2013. During the period from July 2013 to March 2014, the starting date was postponed to the 1st October 2013, then the 1st January 2014, then September 2014. In parallel, social unrest - predominantly in Brittany - caused the destruction of infrastructure dedicated to the écotaxe. Following these events, the project was suspended on the 29th October 2013, and a consultation from the chamber of deputies launched subsequently (Assemblée Nationale, 2014a) suggests, in May 2014, a revision of the tax ambition. On the 8th of August 2014 the écotaxe was redefined and labelled "Péage de transit poids lourds", with a planned starting date of 1st January 2015 (Assemblée Nationale, 2014c). It was finally postponed sine die in October 2014.

In November 2016, the écotaxe was suppressed (Assemblée Nationale, 2016) due to a legal deadline for its implementation (Conseil d'Etat, 2016). In 2017, the "Cour des comptes" the French body in charge of auditing National expenses considered the project a "strategic failure and an expensive withdrawal" and estimated losses at nearly 1 billion euros (957.58 million euros). They identified three main causes: a lack of pedagogy, the surcharging scheme, and weak project management (Cour des comptes, 2017).

Many countries are envisaging or have implemented an ETS taxation system for trucks. Many have tolled motorways too and could be tempted to implement an ETS. The purpose of this paper is to draw lessons learnt from the French attempt, by means of an analysis of the main difficulties observed by business stakeholders at the time.

Data for the paper was collected 'live', in March 2014 - six months before the tax was abandoned. Our empirical approach at the time was aimed at analysing potential implementation challenges of the then, still forthcoming écotaxe in the greater Paris area. We interviewed therefore business stakeholders from the Greater Paris area. Although the écotaxe was not yet operational at the time, infrastructure was already being deployed, on motorways but also in trucks and companies. Feedback obtained concerned in many cases situations that actually happened, and not only expectations or fears. We interviewed presidents, secretary-generals, CEOs or COOs from the four main road transport federations in France, the two main national multimodal transport companies and their federation, a Parisian port agency, relevant shippers, their federations and logistic companies. It was clear from the data obtained that the major stakeholders interviewed expected the new system to come into operation within months and their concerns were mainly about how to best amend it to more fully meet their needs. So why did this promising idea eventually fail to get off the ground? This is the question that this paper sets out to examine.

\section{Review of relevant literature}

In reviewing the relevant literature, the paper will first highlight how transport policy in Europe has a well-established policy framework that includes taxation policy obligations and technological orientations. This represents the policy context under which any national initiative have to operate.

We also review recent literature on road tax acceptance and identify a set of acceptability principles which need to be addressed by policymakers in order to achieve road tax acceptability. We will use these principles as part of our analytical framework in order to illustrate what went wrong in the écotaxe. Finally, our review will examine some of the earlier studies on the écotaxe in France and previous cases of ETS project withdrawals.

\subsection{HGV taxation in Europe: A common vision but different national policies}

HGV taxation systems in Europe have three bases of imposition (see Table 1):

(1) vehicle taxes, imposed based on ownership in the country of registration,

(2) fuel excise duties, related to fuel consumption and the country of refuelling and

(3) user charges, such as vignettes (charged at a fixed rate), tolling systems and other user charges based on a distance/weight basis.

Table 1

Territorial categorisation of charges levied on road freight transport.

Source: Hylen et al. (2013).

\begin{tabular}{|c|c|c|c|c|}
\hline \multirow[t]{2}{*}{ Charges } & \multirow[t]{2}{*}{ Vehicle taxes } & \multirow[t]{2}{*}{ Fuel excise duties } & \multicolumn{2}{|l|}{ User charges } \\
\hline & & & Vignettes & $\begin{array}{l}\text { Tolls + user charges on a distance/ } \\
\text { weight basis }\end{array}$ \\
\hline Description & $\begin{array}{l}\text { "National" charges } \\
\text { relative to the territorial } \\
\text { criterion }\end{array}$ & $\begin{array}{l}\text { Hauliers may choose to not fulfil the } \\
\text { territorial link (filling up in country A } \\
\text { while using roads in country B) }\end{array}$ & $\begin{array}{l}\text { Charges bounded to a specific } \\
\text { territory though not linked to the } \\
\text { quantity used (fixed price) }\end{array}$ & $\begin{array}{l}\text { Charges strictly bounded to a } \\
\text { specific territory and to the } \\
\text { quantity used (price) }\end{array}$ \\
\hline $\begin{array}{l}\text { Territorial } \\
\text { criterion }\end{array}$ & $\begin{array}{l}\text { Nationality based } \\
\text { charges }\end{array}$ & Weakly territorial charges & Moderately territorial charges & Strongly territorial charges \\
\hline Result & \multicolumn{4}{|c|}{ Territorial structure of taxation according to share of fees paid on specific hauls } \\
\hline
\end{tabular}


While vehicle taxes (1) are nationality-based charges, fuel excise duties (2) represent a more refined proxy approach to tax the vehicle use, and user charges (3), are both territorial and closely related to the use of the vehicle. More particularly, tolling systems recover both the capital cost of the infrastructure and its use, whereas other charges can relate to current use of the asset only. Moreover, in tolling systems the (public or private) concession company can collect tolls directly from users to reimburse the investment and to cover maintenance cost. The revenues are therefore earmarked to the infrastructure covered by the concession only. In other charging forms, such as vignettes, road users pay the charge to the public authority, which remunerates the public or private road operator on the basis of predefined contractual terms (ASECAP, 2014).

To understand the process leading to the écotaxe design in its final form, we show in this section how transport taxation in Europe is guided by the EU regulation and vision. Our review shows that this vision is structured by three pillars: (1) a "fair" taxation system for foreign hauliers to ensure that national interests do not restrain free movement of goods, (2) the progressive alignment of taxation levels with the estimated full cost of transport, resulting in the application of the user-pays and polluter-pays principles, usually through user charges on a distance/weight basis, and (3) the use of technology as a mean to achieve seamless taxation.

\subsubsection{A 'fair' taxation for foreign hauliers}

According to Dyrhauge (2014) the Eurovignette directive was originally developed to prevent member states from imposing abusive and discriminatory charges to foreign hauliers. Indeed the Eurovignette process started in 1993, thus before the Kyoto Protocol (1997) and the beginning of "green" taxation. The green and white papers on "Fair" Payment for Infrastructure Use (EC, 1995, 1998) released just before the 1999 Eurovignette Directive (EU, 1999) provide ground for a harmonisation of taxation (Viegas, 2005). Despite the aim of harmonisation behind the Eurovignette Directives, Dyrhauge (2014) considers the system is at best "patchy" and stresses the pre-eminence of economic considerations over environmental ones during the decision-making process. Dyrhauge (2014) identifies "Core" and "Peripheral" countries with distinctive interests concerning the Eurovignette process, due to the larger volume of transit traffic on the road networks in core countries, when compared to peripheral ones.

The distinction between core and peripheral countries is also made by Vega and Evers (2016), who analysed the implications of the UK HGV charge for Irish freight transport stakeholders. Vega and Evers (2016) stress the negative impact of such a charge for the Republic of Ireland, and the disadvantages of peripheral countries with regard to the EU HGV road charging system. Their work illustrates that the initial reasons for the first Eurovignette Directive - fair taxation amongst countries - are still relevant today.

\subsubsection{Charging for the full cost of transport}

In the 1998 and 2001 white papers (EC, 1998, p.8; EC, 2001, p.72) the EC promotes the polluter-pays principle, with the double idea of differentiated taxation depending on truck environmental performance and a taxation that covers not only infrastructure costs but also external costs. In practical terms, it meant the possibility to increase toll fees on the Trans-European Transport Network (TEN-T). The 2011 white paper (EC, 2011) published after the creation of the écotaxe (2009), reinforces these messages by promoting the user-pays and polluter-pays principles as defined in the 2006 Eurovignette Directive. The EC white paper (EC, 2011) also addresses the question of greenhouse gases emission taxation and the idea of a "price-signal" in transport taxation. More specifically, it aims to "Phase in a mandatory infrastructure charge for heavy-duty vehicles", with a "common tariff structure and cost components such as the recovery of wear and tear, noise and local pollution costs to replace the existing user charges" (EC, 2011, p.29).

In parallel, and in line with these recommendations, the Eurovignette Directive 1999/62/EC had been amended twice (by Directives 2006/38/EC and 2011/76/EU). The latter Eurovignette Directive revision includes the "polluters-pays principle" allowing for a differentiated taxation based on the truck environmental performance, such as a $25 \%$ mark-up for Euro I and II vehicles (European Union, 2011).

\subsubsection{Technology: An early vision, but a 'Kafkaesque' situation today}

As early as 2001 the white paper on transport of the European Commission (2001, p. 122) defined that, amongst other targets, “(...) electronic road-charging systems need to be introduced as a matter of priority". Although they promote these systems, EU policymakers are aware of their lack of interoperability: "Electronic road-charging systems and any other automatic fee-collection systems appear particularly useful for restoring balanced prices. The fact that they are now being deployed or are planned in several countries, though not necessarily on a technically interoperable basis as yet, shows how useful it would be for Europe to introduce standards. An interoperability directive needs to be accompanied by Community aid for the deployment of such systems". A report from European Commission (2013) made an ex-post analysis of the Eurovignette Directive and stressed the "great diversity of approaches to the road charging of Heavy Goods Vehicles". The report also provides a review of ETS implementation in Europe (EC, 2013, p.4) and stresses the importance of the ETS systems' harmonisation. 4icom and Steer Davies Gleave (2015) provide a recent review of technical ETS solutions implemented in Europe.

The French ETS was the first designed to comply with the European Electronic Tolling Service (EETS) Directive 2004/52/EC, which entered into force in 2009 (EU, 2004; Mertner and Skov, 2005; Michie, 2012; Guarnieri, 2012) and was considered by the European Commission as a model to be followed (Cour des comptes, 2017). It aimed to ensure interoperability of electronic road toll systems in the European Community. Indeed, a report by the French chamber of deputies highlighted the current "Kafkaesque" situation where a truck that crosses the European Union should be equipped with 11 On Board Units (OBUs) and 5 vignettes (Assemblée Nationale, 2014a). 


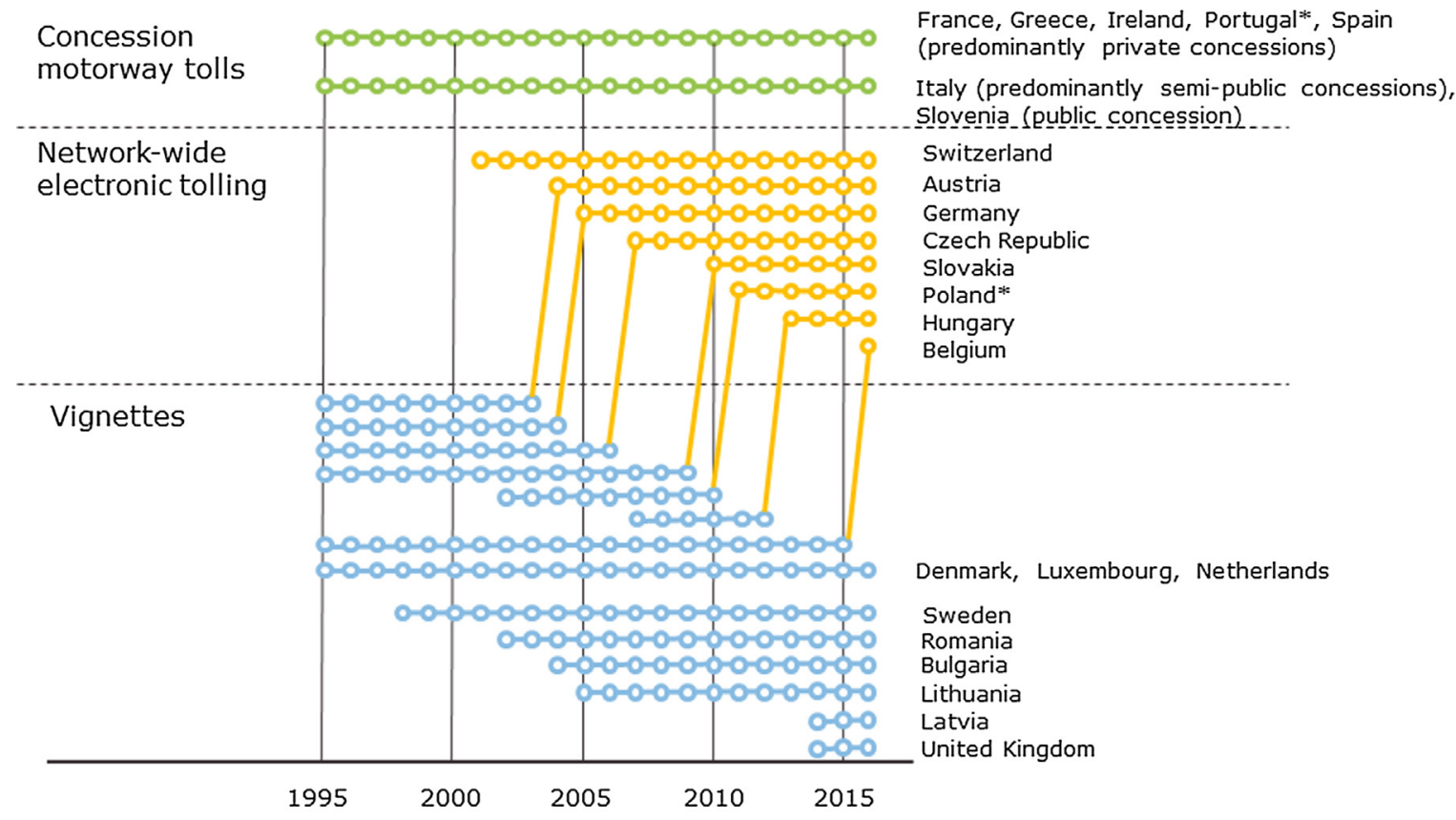

* Portugal and Poland are hybrid cases as in Portugal many of its major motorways are tolled on the full electronic Via Verde system, and Poland has also physical tolls on part of the network

Fig. 1. Development of infrastructure charging systems for heavy goods vehicles in the EU and Switzerland 1995-2016. Source: adapted and updated from CESifo DICE Report 3/2014 and ASECAP (2014).

Fig. 1 illustrates the recent evolution from vignettes to ETS charging in Europe. France is in a category of countries using predominantly tolls, with a network of privately-operated motorways. Among countries in this category, only Portugal managed to develop a hybrid system including a network-wide ETS, largely due to the leading role of the main private concession company, Brisa. Most countries that implemented network-wide ETS charging used previously vignettes and have publicly-operated motorways, with the exception of Poland and Hungary which have mixed systems with both public and private concessions (ASECAP, 2014).

Hylén et al. (2013) and a European Commission (2017) report show that, when compared to taxation via vignettes, large scale distance-based taxation is usually correlated with higher taxation levels. This illustrates that from policymakers' perspective the distance-based system allows for an increase in revenue when compared to the vignette system.

This section showed that transport policy in Europe has a clear regulatory framework that includes taxation policies obligations. These obligations leave much discretion to EU member states over the nature and level of truck charges they impose, so long as they are not discriminatory. The EU framework also defines technological roadmaps. The literature review shed light on the influences that led the écotaxe to be designed as it was: the solution 'put on the table' by policymakers was aimed at reaching a seamless, unified distance-based taxation system and ETS seemed probably the best option to reach it.

\subsection{Road tax acceptability: Principles and cases}

In this section we review the literature on road tax acceptability, and build a framework to analyse the causes that led to the écotaxe withdrawal. Although road tax acceptability is thoroughly studied in the academic sector, most of the work stems from urban and/or congestion charging, where taxes are applied to a larger public than just hauliers. We have compiled 22 works from recent literature analysing both implementation and withdrawals cases, which are summarised in Appendix A. Only four of these papers address exclusively the HGV sector (Herry, 2005; McKinnon, 2006a; McKinnon, 2006b; Link, 2008) and two more analyse it in a dedicated section of the paper (Sorensen and Taylor, 2006; Sorensen et al., 2014) but don't identify acceptability principles specifically for the HGV sector. From these 22 papers we have identified 13 major principles to be addressed by policymakers in order to achieve road tax acceptability (Table 2).

\subsubsection{Acceptability applied to ETS charging for HGV in Europe}

Among HGVs stakeholders, equity, the most cited principle, is often considered from the "user-pays" perspective. This principle is used as a means of charging foreign HGV operators for the maintenance of road infrastructure (Sorensen and Taylor, 2006). This 
Table 2

Number of citations addressing identified road tax acceptability principles in papers reviewed (see details in Appendix A).

\begin{tabular}{ll}
\hline Acceptability principles & Citations in papers \\
\hline Equity (outcome) & 18 \\
Earmarking of revenues & 13 \\
Cost efficiency & 9 \\
Behavioural effectiveness & 9 \\
Alternatives and "package" policy & 7 \\
Social effectiveness & 6 \\
Revenue-neutral policy & 6 \\
Privacy & 6 \\
Basic rights & 6 \\
System reliability and trust & 6 \\
Equity (policy design process) & 5 \\
Information and communication & 4 \\
Problem identification & 4 \\
\hline
\end{tabular}

purpose was observed in Germany, Austria, Czech Republic and Belgium. It was also observed in France and UK where the projects were withdrawn: Ollivier-Trigalo (2013) shows how the traffic generated in France from the LKW-Maut gave the first impetus to the French écotaxe project, and McKinnon (2006a) indicates how the emergence of the "foreign haulier", due to the cabotage liberalisation, was a critical factor for the launch and initial acceptability of the Lorry Road User Charging (LRUC) project. Also, road taxation has an intrinsic vertical inequity as charges are not differentiated depending on the commodity transported and therefore shippers manufacturing products with lower value will proportionally be more impacted by the tax. Such a study has been carried out by Doll and Schaffer (2007) for the LKW-Maut and showed little differences, with total commodity price impact varying from $0.07 \%$ to $0.20 \%$ for selected commodities.

The 'equity of the design process' is usually ensured by means of interactions between policymakers and transport stakeholders representatives.

The 'earmarking of revenues' is widely applied in the HGV sector as in general road taxation: many recent ETS implementation revenues are earmarked to the road transport sector (Austria, Czech Republic) or to the transport sector in general (Switzerland, Germany, Poland) with some variations such as Belgium where excess revenues might be used in other areas of expenditure (European Commission, 2017).

The 'cost efficiency' principle gained momentum with the development of ETS technologies, where collection costs vary from the range 6-15\% of tax revenues (Switzerland, Austria, Czech Republic and Germany), to values from 20\% and above (Belgium, Poland and Germany at launch). In many countries where the system was withdrawn (France, UK, Denmark) collection costs were expected to be above $20 \%$. As a matter of comparison, the collection cost of the French axle tax, considered high, was estimated at $11 \%$ in 2014 (Liechti and Renshaw, 2006; Nowacki and Niedzicka, 2009; Walker, 2011; Assemblée Nationale, 2014a).

'Behavioural effectiveness' is often achieved in the HGV sector via mandatory rules (forbidden roads sections, days of week or times slots). In road taxation this principle is usually applied using differentiated tax pricing in domains where transporters or shippers are the decision-makers, such as the purchase of efficient trucks, the use of multi-modal transport, the truck loading factor or the choice of routes. Results seem to indicate a correlation between the implementation of ETS and a small increase in truck loading factors, and where there are differentiated pricing for Euro classes, an increase in use of trucks with higher Euro standards. However, no significant impact has been observed in multimodal transportation and unwanted effects of traffic diversion towards untaxed roads were observed (Kossak, 2012; Liechti and Renshaw, 2006; McKinnon, 2006b).

The 'package policy' principle aims to provide alternatives to compensate for the burden of the tax. In the freight sector this is done by earmarking revenues to develop modal transfer infrastructures, although multimodal transport has often a limited scope to increase. Switzerland offered as a compensation a higher maximum laden weight, and Germany implemented a system to help transfer to Euro 6 trucks (Doll and Schaffer, 2007; Assemblée Nationale, 2014a, p. 57).

The 'revenue-neutral' principle was applied in the UK for its vignette in 2014 and was an objective of the LRUC (McKinnon, 2006b). In general, from hauliers' perspective taxation can be perceived as revenue-neutral as long as they believe they can pass costs on to shippers. This belief was highlighted by Link (2008) as one of the variables for HGV road tax acceptability. In fact, as seen previously, ETS charging schemes for HGV are generally not revenue neutral and are often associated with an increase in taxation.

'Privacy' and 'Basic rights' appear to be less significant for trucking companies than individuals, probably as major operators are already equipped with a range of tracking systems and are used to restrictions in the use of HGV transport.

'System reliability and trust' principle also gained momentum with the emergence of ETS technologies, but the experience gained with current systems should in theory reduce this concern over time. McKinnon (2006a, 2006b) for instance, suggested to postpone a country-wide ETS implementation in the UK until solutions were robust and interoperable. He proposed a "low-tech" alternative 
Table 3

Attributed causes of road taxation withdrawal for selected cases.

\begin{tabular}{|c|c|}
\hline Case (year) & Attributed causes of withdrawal \\
\hline Hong Kong (1985) & $\begin{array}{l}\text { The Hong Kong case was a 2-year urban electronic road pricing experiment that was not extended after the trial phase as district } \\
\text { boards did not support the scheme, leading to a lack of political support. Existing literature attribute causes to public concerns } \\
\text { about privacy and not considering traffic conditions bad enough, associated with a lack of governmental communication to } \\
\text { promote the scheme (Vonk Noordegraaf et al., 2014) }\end{array}$ \\
\hline Paris Cofiroute toll (1996) & $\begin{array}{l}\text { The scheme was a motorway toll, with four time bands, each with differentiated toll rates. It was cancelled as users considered it } \\
\text { too complex and drivers speeded on feeder roads to arrive on time at the charging points (Bonsall et al., 2007) }\end{array}$ \\
\hline Lyon ring toll (1997) & $\begin{array}{l}\text { A toll was implemented on a newly built city ring. It was rejected by lawsuit after a public boycott, with road obstruction and } \\
\text { infrastructure destruction. The main cause attributed to this revolt was the suppression of alternative routes to the tolled one (Raux } \\
\text { and Souche, 2000, 2001; Bonsall et al., 2007) }\end{array}$ \\
\hline UK LRUC/NRUC (2005) & $\begin{array}{l}\text { The UK attempted to implement a national distance-based charging scheme (NRUC), which could be initially applied on lorries } \\
\text { (LRUC). The decision was paused in 2005. A probable cause of the withdrawal is the lack of consensus on its objective: it did not } \\
\text { seem clear whether it would be a congestion charge, an infrastructure charge or a charge on foreign lorries using UK } \\
\text { infrastructures. The limited volume of transit traffic in the UK (5\%), the expected collection cost of the ETS solution (24\%-64\%) } \\
\text { and its complexity probably contributed to the LRUC withdrawal. It was ultimately replaced by a vignette and an equivalent } \\
\text { reduction of Vehicle Excise Duty (VED) for UK trucks. (McKinnon, 2006a, 2006b; Bonsall et al., 2007; Walker, 2011). In 2017, } \\
\text { distance-based HGV taxation was still being considered as a valid policy option (DfT, 2017) }\end{array}$ \\
\hline Edinburgh cordon (2005) & $\begin{array}{l}\text { Rejected by referendum due to equity concerns and lack of public support. People preferred the use of individual cars and did not } \\
\text { believe in the objectives of congestion reduction and investment in public transport. (Sorensen and Taylor, 2006; Albalate and Bel, } \\
\text { 2009; Ecola and Light, 2009; Anas and Lindsey, 2011; Walker, 2011; Vonk Noordegraaf et al., 2014) }\end{array}$ \\
\hline Manchester cordon (2008) & $\begin{array}{l}\text { Also rejected by referendum, with causes likely similar as the Edinburgh ones. (Levinson, 2010; Anas and Lindsey, 2011; Walker, } \\
\text { 2011) }\end{array}$ \\
\hline Manhattan cordon (2008) & $\begin{array}{l}\text { New York City could not move forward with the project due to disagreements between the city and surrounding districts about the } \\
\text { charge impact on surrounding districts and the distributing of the funds. The principal objections were not focused on whether the } \\
\text { pricing plan would actually reduce traffic congestion. (Albalate and Bel, 2009; Ecola and Light, 2009; Anas and Lindsey, 2011) }\end{array}$ \\
\hline Netherlands (2010) & $\begin{array}{l}\text { The plan to introduce a kilometre charge (Anders betalen voor Mobiliteit) was paused due to a lack of political support after the } \\
\text { elections of March } 2010 \text { (Lindsey, 2010; Walker, 2011; RDW, 2012; Duncan and Graham, 2013) }\end{array}$ \\
\hline Denmark (2012) & $\begin{array}{l}\text { Paused in } 2012 \text { following the Dutch vote (Kossak, 2012). Early simulations also showed high level of expected running costs } \\
\text { (34-37\%) for ETS wide charging. (Rapp and Hansen, 2007) }\end{array}$ \\
\hline
\end{tabular}

based on three key elements: (1) a charging matrix with truck-dependent tariff differentiation, (2) distance measurement measured annually directly on tachographs and (3) a fuel duty rebate scheme to the minimum allowed by the EU to ensure revenue-neutrality.

'Information and communication' is still an important principle for implementing ETS in the freight sector, since many transport operators are individual or small-sized companies making information more difficult to reach them.

Finally, the 'problem identification' must be clearly addressed, in order to create a consensus about the aggregate social welfare being considered and therefore be able to create a policy with a convincing 'social effectiveness'. The LRUC case seems to be a good example of a tax with a "loosely defined" purpose, which was not implemented (McKinnon, 2006a). The system was presented altogether as a congestion charging scheme and as a way to tax foreign hauliers, but without significant supplementary revenue to fund transport infrastructure.

\subsubsection{Previous withdrawal cases: A review}

Among the papers reviewed, detailed analyses of withdrawals are scarce as the literature tends to focus mainly on successful implementations (see Appendix A). Table 3 illustrates the withdrawal cases cited in these papers, with a synthesis of attributed causes. We have added the case of Denmark, which was not analysed in the papers reviewed.

The review shows that ETS project withdrawals can be attributed to many causes, but they have as a common ground the lack of political consensus. This lack of consensus allowed projects to be withdrawn at earlier stages than in France. The political consensus observed in France until the last stages of the implementation process probably explains why it collapsed at such a late stage. The review also shows that France had already experienced, in a smaller scale, an episode of riots and tolling infrastructure destruction concerning the Lyon ring toll in 1997.

For further literature about transport pricing, the reader is invited to consult the extensive work produced since the early stages of ETS implementation in Europe in the several special issues in the following journals: Transportation Research Part A (2007, 2009, 2010, 2017), Transport Policy (2005, 2006) and Research in Transport Economics (2004, 2005, 2007).

\section{Description of the case}

The écotaxe collection was based on an OBU (On-Board Unit) system that combines the position of trucks (using Global Navigation Satellite System), with the taxed zones and the truck specifications. The information would then be transmitted via 
General Packet Radio Services for taxation purposes. A Dedicated Short Range Communication (DSRC) system would ensure the conformity between the OBU and the truck. Regular users could use the standard automatic toll card used in French motorways and infrequent users would have to buy the appropriate OBU. The DSRC installed on motorways that drew so much attention during the social unrest stage, were actually not necessary for the system to work (conformity could be ensured by classic police control). The system would be operated by a consortium of private companies, led by the Italian company "Autostrade per l'Italia". As it would be the first compatible with the EETS Directive, it would ensure seamless taxation between France, Portugal and the upcoming Belgian system.

\subsection{Genesis and withdrawal of the tax}

Historically, the road taxation system in France is a combination of the three charges:

(1) the axle tax, for the vehicle, implemented in 1968 (Olliver-Trigalo, 2013)

(2) the fuel levy of 43.1 eurocents per litre, partially refunded. It was increased by 4 cents after the écotax postponement

(3) physical tolls as user charges, introduced in 1955. The écotaxe is a user charge.

Ollivier-Trigalo $(2012,2013)$ provides a comprehensive review of the écotaxe genesis and highlights six recurring themes reflecting the interviewees' main reactions towards the écotaxe:

- "Road freight transport doesn't cover its costs"

- "Road freight transport is necessary to the functioning of the economy"

- "Road freight transport does have environmental protection practices, alternatives to the tax"

- "Taxation of HGV must incentivise modal transfer"

_ "Transport infrastructures need new and long-lasting sources of financing"

- "HGV tax is an instrument of environmental taxation"

Ollivier-Trigalo $(2012,2013)$ highlights several influences in the genesis of this tax: the German LKW-Maut, which generated questions about the potential traffic diverted into roads of neighbouring Alsace, the newly elected government in 2007 and the subsequent "Grenelle" agreements signed in 2009, and the European framework (Eurovignette and EETS Directives). The author also describes the design process of the surcharging scheme towards the shippers. The author shows that much attention was given to this scheme and that policymakers were concerned about potential discrepancies between the écotaxe value and the amount surcharged (Ollivier-Trigalo, 2012, 2013).

The idea of a surcharging scheme was a "founding principle" of the écotaxe (Sénat, 2013, p. 30) and was accepted at the very early stages of the tax genesis during the "Grenelle" agreements in 2007. Its aim was to allow road hauliers to pass on the costs from the tax while applying the polluter-pays principle to the actual final beneficiaries of the transport, the shippers. The initial scheme was to split transport operations depending on transport modes and, for Full Truck Load transport to transfer the actual amount paid on the invoice. However, calculations seemed too complex to apply during the time elapsed between the transport execution and the invoice submission, hence the idea of an ad valorem rate for all transport operations (Journal Officiel, 2012, Ollivier-Trigalo, 2012, p. 84; Sénat, 2013, p. 30).

Harnay (2012) and Harnay and Rème (2012) studied the abandonment of carbon taxation in France for road transport, and showed that the écotaxe was created in a context where transport federations were also negotiating the abandonment of a carbon tax for trucks. Ollivier-Trigalo (2013) stated that the privatisation of motorways created the need for additional taxation (namely, the écotaxe) to increase revenues.

After the first postponements in 2010-2012, the French Economic Council (CEDD, 2013) analysed some weaknesses of the écotaxe as it had been up to then designed. It pointed overall to a lack of communication towards the public, especially the need to: clarify the objectives of the tax, re-examine the communication on the earmarking, clarify how investments would be in line with the communicated ecological aspect of the tax (how investments would increase modal transfer), and to show how the amount proposed covered the real costs of transport.

\section{The withdrawal process: Political context and ex-post analyses}

The écotaxe project started to face postponements as early as 2010. Earlier postponements were due to legal and administrative problems related to the tendering process. These are described in Ollivier-Trigalo (2013) and Assemblée Nationale (2014a) and will not be detailed here. In the summer 2013, Ecomouv, the tax collection consortium organised a 'go-live' trial with selected hauliers, in conjunction with a transport federation. Some technical and user-interface problems were observed, such as taxation errors and difficulties for hauliers to understand the taxation rules. Simultaneously, the question of the policy itself gained momentum over the technical points. Riots had started in August 2013, near two agri-industry plants in Brittany (poultry and pork), one of which was closing a site and laying off personnel. The difficulties of this industry were not related to the écotaxe, but due to competition from countries with lower labour cost. In this context, during a gathering labour union members destroyed écotaxe infrastructures. 
Table 4

Écotaxe rates as of 1st January 2014, in euro cents per $\mathrm{km}$.

\begin{tabular}{llll}
\hline & 1st cat. & 2nd cat. \\
\hline Electric vehicles & 5.3 & 6.7 & 3rd cat. \\
EURO VI (and EURO V VRE) & 7.5 & 9.4 & 10.5 \\
EURO V & 8.4 & 11.1 & 13.1 \\
EURO IV & 8.8 & 12.2 & 15.6 \\
EURO III & 9.7 & 12.8 & 16.9 \\
EURO II & 10.1 & 13.3 \\
EURO I and prior & 10.6 & 17.7 \\
\hline
\end{tabular}

Differently from other French regions, Brittany had never had road taxation up to then. As a consequence of these riots, the implementation process was temporarily suspended in October 2013. Our own consultation started in March 2014. Although our dataset does not cover Brittany, it shines a light on an important point about the stakeholders' perception: the écotaxe would be seen as a 'local' tax more than a tax on foreign hauliers and imported products. A new government arrived in April 2014, and after a consultation published in May (Assemblée Nationale 2014a), the government decided in September 2014 to withdraw the tax.

The main reasons for this withdrawal will be presented in the results section, however a number of political factors should be highlighted. Firstly, as previously indicated, the nomination of a new government in May 2014, hence free from previous political commitments. Secondly, a change of political majority in 2012 allowed a partial exemption of the current majority from political responsibility, since most of the écotaxe's policies and technological choices were made under the previous one. Finally, a sequence of tax rises that saw the overall tax burden increase from $41.3 \%$ of GDP in 2009 to $45.2 \%$ in 2013 may have created a context of higher sensitivity towards taxation.

There is little academic work commenting on the withdrawal process. Chiroleu-Assouline (2015) discusses green taxation in France but does not focus on the écotaxe. The author attributes its failure to the lack of political will and strength from government when confronted with social unrest and lobbies (Chiroleu-Assouline, 2015, p.150).

The most complete analysis from that period is provided by a report following the chamber of deputies consultation (Assemblée Nationale, 2014a), that aimed amongst other to "reestablish (écotaxe) legitimacy with regard to the orientations that prevailed at its design". The report was published in May 2014, soon after our own feedback to policymakers. It is the first report to put the spotlight on the relation between the écotaxe implementation difficulties and the privatisation of French motorways in the years 2000 . It also highlights, in combination with another report from the Assemblée Nationale (2014b), the potential benefits that motorways private operators could have with the écotaxe, considering the expected transfer of traffic from some national taxed roads to the motorways. However, although the report provides a good diagnosis of the situation, it does not question the principle itself of the surcharging scheme and only suggests an improved and less ambitious version of the tax. It suggests the creation of a HGV eco-fee ("écoredevance poids lourds"), as a replacement for the écotaxe.

In 2017, the Cour des comptes (2017) published a report assessing the total cost and the causes of failure. The Cour des comptes defines itself as "the supreme body for auditing the use of public funds in France. It is independent from the Government and Parliament. It has financial jurisdiction and is in charge of auditing, issuing rulings and certifying the State and Social Security accounts, as well as contributing to the evaluation of public policies". Among different causes of the implementation failure, it stresses inadequate selling of the écotaxe rationale and the inadequate surcharging system. The report focuses mostly on the financial cost of withdrawal rather than analysing in detail the causes of the écotaxe abandonment.

\subsection{The écotaxe charging and surcharging schemes}

\subsubsection{The charging scheme: A road coverage excluding motorways and modulated rates}

French motorways were privatised in the period from 2002 to 2006. Supplementary taxation on tolled motorways would subsequently necessitate delicate negotiations with different concession companies which had already paid more than 15 billion euros in total for the right to operate motorways until the years 2027 to 2033 (Assemblée Nationale, 2014b). Furthermore, the tax amount potentially transferred to the government would be limited by the Eurovignette Directive, applicable in motorways and the TransEuropean Transport Network (TEN-T), which stipulated that the maximum average tolls must be set in relation to the costs of constructing, operating and developing the infrastructure concerned (which was already the case with the price of tolls). Therefore it was decided since the first écotaxe formulation during the Grenelle agreements in 2007 that it would only be applied to national roads, local roads or to toll-free motorways sections. In the final stages of the écotaxe implementation process, a report from the Cour des Comptes (2013), pointed out the weak public control over the private concessionaries and the lack of governmental negotiation power with respect to the limitation of toll rates increase.

Following the "polluters-pay principle" of Eurovignette III, the charging rates depended on the Euro class of the vehicle and its category (Table 4). 
Table 5

Écotaxe surcharging rates as of 1st January 2014, in ad valorem percentage of invoice.

\begin{tabular}{|c|c|c|c|}
\hline Region & Rate & Region & Rate \\
\hline Ile-de-France & $7.0 \%$ & Pays de la Loire & $3.9 \%$ \\
\hline Alsace & $6.9 \%$ & Auvergne & $3.8 \%$ \\
\hline Nord-Pas-de-Calais & $6.7 \%$ & Bretagne & $3.7 \%$ \\
\hline Limousin & $6.0 \%$ & Centre & $3.6 \%$ \\
\hline Lorraine & $5.7 \%$ & Rhône-Alpes & $3.4 \%$ \\
\hline Champagne-Ardenne & $5.5 \%$ & Franche-Comté & $3.3 \%$ \\
\hline Basse-Normandie & $4.6 \%$ & Midi-Pyrénées & $2.8 \%$ \\
\hline Poitou-Charentes & $4.6 \%$ & Provence-Alpes-Côte d'Azur & $2.7 \%$ \\
\hline Bourgogne & $4.3 \%$ & Aquitaine & $2.3 \%$ \\
\hline Picardie & $4.1 \%$ & Languedoc-Roussillon & $2.1 \%$ \\
\hline Haute-Normandie & $4.1 \%$ & Corse & $0.0 \%$ \\
\hline
\end{tabular}

The categories are defined as follows:

- First category: 2 axles maximum and total laden weight between 3.5 and 12 tonnes

- Second category: 3 axles maximum and total laden weight higher than 12 tonnes

- Third category: 4 axles and more

\subsubsection{The surcharging scheme: A unique system designed to pass the tax costs to shippers}

In contrast to other countries where ETS had been implemented, where shippers and hauliers have the flexibility to negotiate pricing adjustments at their own commercial discretion, French authorities, in collaboration with business stakeholders, decided to implement a mandatory surcharging system for hauliers. It would allow hauliers to increase the invoice by an ad valorem ratio that would depend on the regions where the transport occurred. The system would work as follow:

- Each region would have a ratio depending on the cost generated by the expected average mileage hauliers would drive on taxed routes. The ratios varied from $0 \%$ in Corsica, which had no taxed road, up to $7 \%$ in Paris regions (Ile-de-France) where most significant roads were taxed, as shown in Table 5 (as of 1st January 2014).

- For transports between regions a standard rate of $5.2 \%$ had been defined.

The target was to define a surcharging system that was "simple, practical, and understandable" (Ollivier-Trigalo, 2012, 2013). The idea of a surcharging scheme for the écotaxe originated in 2007 during the "Grenelle" agreements. At the time, a similar ad valorem system for the fuel surcharge in road transport had been implemented (Journal Officiel, 2006). Road hauliers and shippers were therefore already familiar with the concept.

\section{Methodology}

This paper takes a qualitative approach. It seemed the most appropriate at the time as the objective was to explore the écotaxe impacts, as they were perceived by the business stakeholders. Herry (2005, p. 86) stated that when studying new taxation acceptability, research has "tended to stay away from rational models that consider only global "social collective" interest without looking

Table 6

Interviews number by organisation type and sector.

\begin{tabular}{ll}
\hline Type & Interviews \\
\hline Federation & 11 \\
Company & 10 \\
Sector & Interviews \\
\hline Road transport & 7 \\
Shipper & 7 \\
Multimodal transport & 3 \\
3PL & 2 \\
Logistics Real Estate & 1 \\
Port & 1 \\
\hline
\end{tabular}


Transport activity in Paris Region by NST (2014)

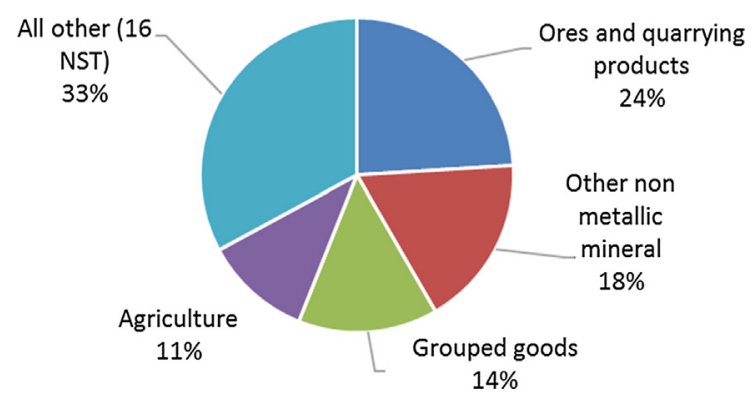

Fig. 2. Transport activity by NST commodity class. Source: SitraM database, http://www.developpement-durable.gouv.fr.

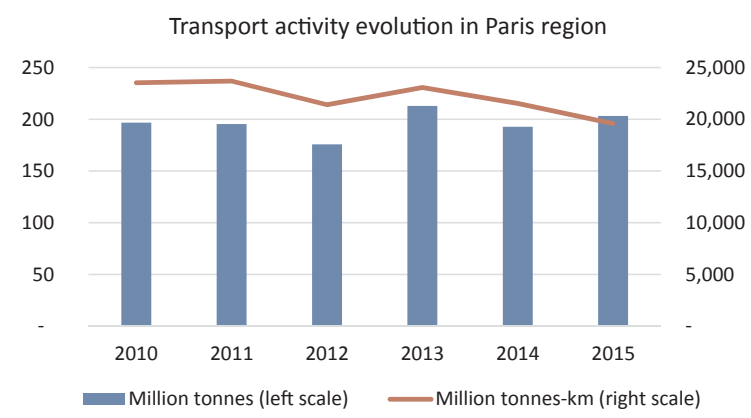

Fig. 3. Transport activity evolution. Source: SitraM database, http://www.developpement-durable.gouv.fr.

at its redistributive implications. This is where we find empirical studies, e.g. studies making use of questionnaires and interviews, and ex-post studies". Vega and Evers (2016) used recently an approach through interviews for the analysis of the UK taxation scheme in Ireland.

As previously stated, the original intention of the research was to talk to primary business stakeholders and get a deep understanding of their difficulties and perception towards the then forthcoming, écotaxe. Therefore, our empirical approach addressed issues such as the expected impacts of the écotaxe in their business activity. We believe that the feedback obtained at that specific time is late enough in the process to include information from the pilot phase (summer 2013) and from the annual price negotiations between shippers and hauliers (fall 2013). Also, because the écotaxe was planned to go live on 1st of September 2014, we have a feedback from business stakeholders concerning the tax acceptance that precedes the announcement of the sine die postponement.

Twenty-one semi-structured interviews were carried out, with an average duration of $1 \mathrm{~h} 30$. Some of these involved multiple interviewees in a single session (36 interviewees in total). One of the interviews was a focus group where many small hauliers attended, however only the three workshop organisers, who lead the answers, are detailed in Table 6 . The interviews were conducted in French and all transcripts were submitted for validation by the interviewees. We provided summary feedback on the results of the interviews to business stakeholders in a form of workshops held in March and April 2014, and provided to policymakers a detailed report.

\subsection{Interview panel}

The set of interviewees was purposively sampled in order to be representative of the transport activity in the Paris region.

Fig. 2 shows that four types of products represent $67 \%$ of all activity in Greater Paris area: Ores and quarrying products, mineral products, grouped (palletised) goods, and agriculture goods. The average distance travelled is small: about $31 \mathrm{~km}$ for domestic flows and $230 \mathrm{~km}$ for inwards/outwards flows. Fig. 3 shows that although the activity is relatively steady in tonnages, it is in decline in terms of transport work (t.km). Transport activity is defined here as the sum of inbound, outbound and domestic (intra-region) flows.

In line with the transport activity presented in Fig. 2, the panel consisted of:

- Representatives of shippers for the biggest four commodities transported in Paris regions (67\% of the tonnage transported, as shown in Fig. 3), and their federations,

- Representatives of the main French transport federations,

- Representatives of two main French multimodal companies (44\% of market share) and their federation, 
Table 7

Interviewees and interviews attributes.

\begin{tabular}{|c|c|c|c|c|c|}
\hline Organisation profile & Type & Sector & Duration (mins) & Word count & Interviewees \\
\hline Transport users federation & Federation & Shipper & 90 & 1406 & $\begin{array}{l}\text { 1. Deputy Delegate-General } \\
\text { 2. Road commission President }\end{array}$ \\
\hline Agriculture production cooperative & Federation & Shipper (food) & 90 & 960 & $\begin{array}{l}\text { 3. Sustainable Food Chain Director } \\
\text { 4. Advisor for Energy \& Supply Chain }\end{array}$ \\
\hline 3PL (1) & Company & 3PL & 45 & 534 & 5. COO for Retail in Paris region \\
\hline Logistics Real Estate & Company & Logistics Real Estate & 30 & 685 & 6. Associate Director \\
\hline Commerce \& Distribution federation & Federation & Shipper (retail) & 90 & 1362 & $\begin{array}{l}\text { 7. Environmental Advisor } \\
\text { 8. Transport coordinator for Paris region }\end{array}$ \\
\hline Road transport federation (1) & Federation & Road transport & 90 & 1469 & 9. Secretary-General for Paris region \\
\hline Building sector federation & Federation & Shipper (building) & 120 & 1054 & $\begin{array}{l}\text { 10. President for Paris region } \\
\text { 11. Secretary-General for Paris region }\end{array}$ \\
\hline 3PL (2) & Company & 3PL & 90 & 1452 & 12. CSR Manager \\
\hline Multimodal transport federation & Federation & Multimodal transport & 120 & 869 & 13. Delegate-General \\
\hline Road haulier (1) & Company & Road transport & 45 & 772 & 14. Operations Support Director, France \\
\hline Food producers \& wholesalers & Federation & Shipper (food) & 90 & 1371 & $\begin{array}{l}\text { 15. President (Fruits \& Vegs Federation) } \\
\text { 16. Local President (Fruits \& Vegs Federation) } \\
\text { 17. CEO (Wholesalers Federation) } \\
\text { 18. Secretary-General } \\
\text { 19. Studies and Statistics Manager }\end{array}$ \\
\hline Multimodal transport company (1) & Company & Multimodal transport & 90 & 869 & 20. President \\
\hline Multimodal transport company (2) & Company & Multimodal transport & 60 & 1027 & 21. CEO \\
\hline Road transport federation (2) & Federation & Road transport & 90 & 1668 & $\begin{array}{l}\text { 22. Deputy Secretary-General } \\
\text { 23. President for Paris region } \\
\text { 24. Secretary-General for Paris region } \\
+8 \text { road hauliers }\end{array}$ \\
\hline Port Authority & Company & Port & 180 & 1331 & $\begin{array}{l}\text { 25. Deputy Director } \\
\text { 26. Sustainable Development Manager } \\
\text { 27. Mining and Building representative }\end{array}$ \\
\hline Road haulier (2) & Company & Road transport & 60 & 928 & $\begin{array}{l}\text { 28. Marketing \& Sales Director } \\
\text { 29. Sales development Director }\end{array}$ \\
\hline Cereals production company & Company & Shipper (cereals) & 60 & 712 & 30. $\mathrm{COO}$ \\
\hline Refrigerated transport company & Company & Road transport & 90 & 791 & 31. CEO \\
\hline Road transport federation (3) & Federation & Road transport & 90 & 1103 & $\begin{array}{l}\text { 32. Director-Delegate } \\
\text { 33. Regional Director }\end{array}$ \\
\hline Mining \& Building material federation & Federation & Shipper (building) & 90 & 742 & $\begin{array}{l}\text { 34. President for Paris region } \\
\text { 35. Secretary-General for Paris region }\end{array}$ \\
\hline Refrigerated transport federation & Federation & Road transport & 90 & 1324 & 36. Delegate-General \\
\hline
\end{tabular}

- Logistics and transport providers (see Tables 6 and 7 for a more detailed breakdown).

The semi-structured interviews were guided by a questionnaire structured in four parts:

- in the first part, the interviewees were asked to introduce themselves and their organisation,

- in the second part they described their logistic organisation, costs, and management principles,

- in the third part we addressed how the interviewees were managing the run up to the écotaxe,

- the fourth part was open to let the interviewees add any issue they wanted.

In the third part, concerning the écotaxe management, we did not address any preconceived principle, expected impact or anticipated consequences. When a topic (or theme) was mentioned by an interviewee, interviewers, when appropriate, tested it with subsequent interviewees. Typically, questions would be purposely open and without positive or negative bias about the écotaxe: "how did you manage the situation?", "what are the consequences for your organisation?", "what actions have your organisation implemented?", "with what other services or organisations have you engaged?", etc.

Table 6 summarises the interviews number by organisation type and sector. Table 7 shows the detailed interviewees list and the interviews attributes.

After validation by the interviewees, the corpus was coded using an exploratory, inductive approach. One or two topics were associated to every text string. If required, the interviewee opinion about this topic was classified as a sub-topic. Once the data was coded, the coding frequency was used to measure the time spent by interviewees on specific topics, and therefore are used to illustrate - as a proxy - the centrality and/or complexity of the topic. A more detailed description of the data processing is provided in Appendix B. 


\section{Range of topics covered over time}

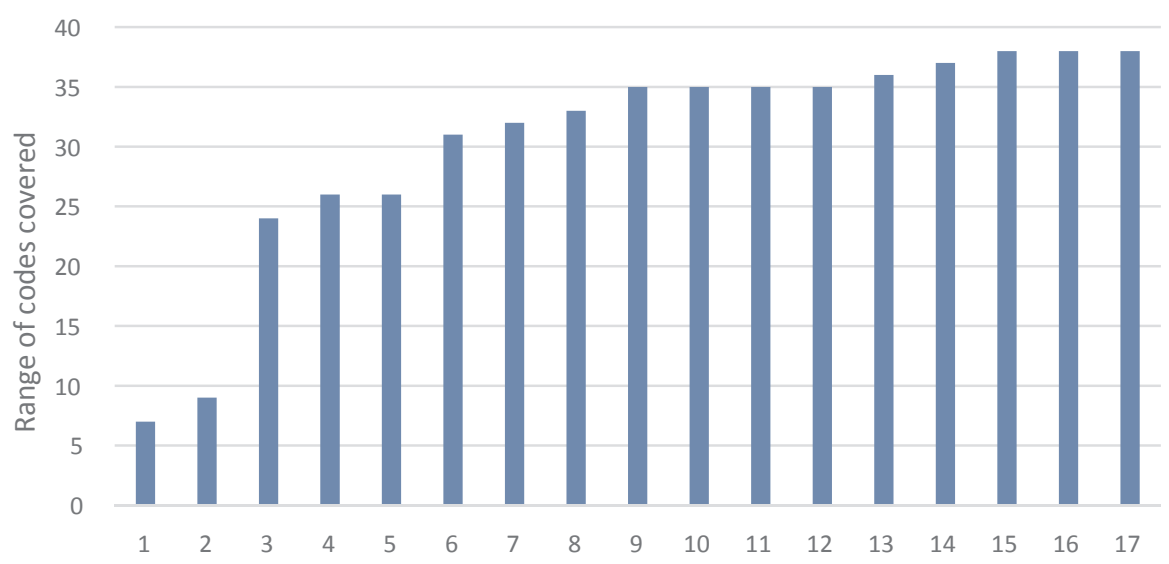

Interview days (ordered)

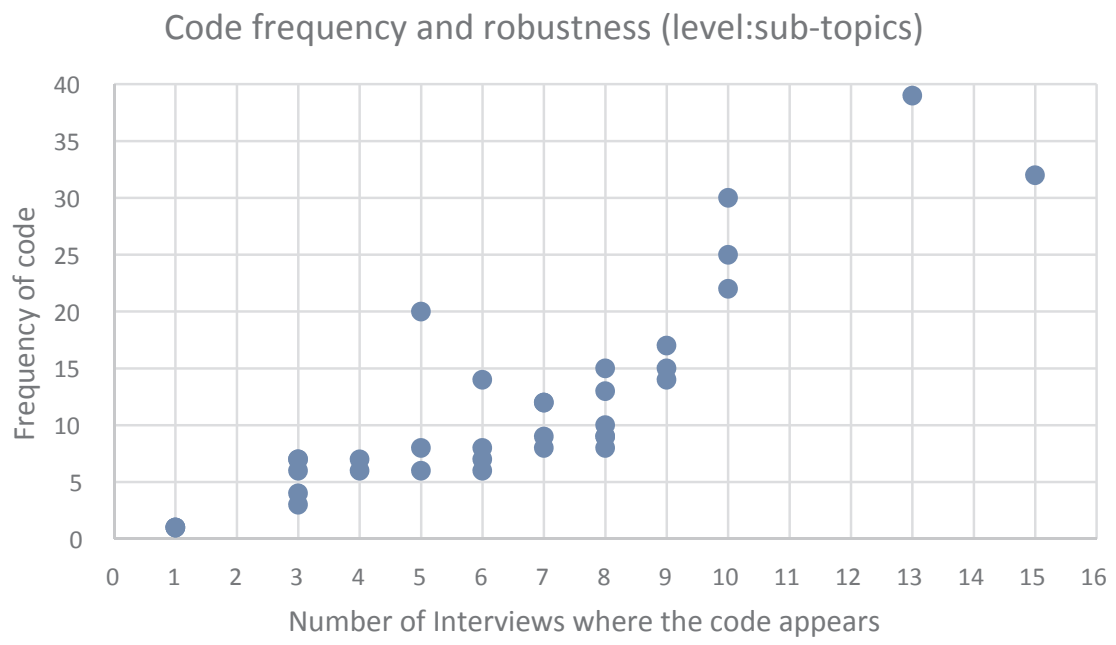

Fig. 4. Analysis of codes frequency exhaustiveness (top) and robustness (bottom).

Table 8

Main topics resulting from the coding process.

\begin{tabular}{|c|c|c|c|}
\hline Topics (ordered by number of interviews) & \# Interviews (/21) & Code frequency & \# Road transport (/7) \\
\hline 1. Competitive inequities & 18 & 84 & 7 \\
\hline 2. Ad valorem surcharge & 18 & 78 & 7 \\
\hline 3. Haulier/Shipper relationships & 16 & 63 & 7 \\
\hline 4. Investments issues (IT/OBU) & 15 & 51 & 7 \\
\hline 5. Further questions/Uncertainty & 15 & 32 & 6 \\
\hline 6. Principle of a tax & 11 & 27 & 4 \\
\hline 7. Alternative taxation - UK/DE Benchmark & 10 & 30 & 4 \\
\hline 8. Sectorial aspect: scope of transport service vs scope of tax & 10 & 25 & 3 \\
\hline 9. Feedback on test period & 7 & 15 & 4 \\
\hline 10. Delocalisation risks & 6 & 14 & 4 \\
\hline 11. Difficult context - transport costs rising & 8 & 13 & 4 \\
\hline 12. OBU Ownership by shipper & 8 & 9 & 4 \\
\hline 13. Administrative costs of écotaxe & 8 & 8 & 4 \\
\hline 14. Sub-contracting issues & 3 & 7 & 2 \\
\hline 15. Tax avoidance - alternative routes are not possible & 6 & 6 & 4 \\
\hline Total & 21 & 462 & 7 \\
\hline
\end{tabular}


Table 9

Detailed coding outcome.

\begin{tabular}{|c|c|c|c|c|}
\hline $\mathrm{Nb}$. & Topics \& sub-topics & \# Interviews (/21) & Coding frequency & \# Road transport (/7) \\
\hline 1.1 & Competitive inequities - Foreign vs national production & 5 & 20 & 1 \\
\hline 1.2 & Competitive inequities - Foreign vs national hauliers & 6 & 7 & 2 \\
\hline 1.3 & Competitive inequities - Large vs small hauliers (complexity) & 7 & 12 & 3 \\
\hline 1.4 & Competitive inequities - Own-account vs externalised transport & 10 & 22 & 3 \\
\hline 1.5 & Competitive inequities - Short vs long distances & 8 & 15 & 1 \\
\hline 1.6 & Competitive inequities - Small vs large trucks & 5 & 8 & 1 \\
\hline 2.1 & Ad valorem surcharge - cause of tax rejection & 1 & 1 & 0 \\
\hline 2.2 & Ad valorem surcharge - complex & 8 & 10 & 2 \\
\hline 2.3 & Ad valorem surcharge - modal transfer - does not promote & 7 & 12 & 3 \\
\hline 2.4 & Ad valorem surcharge - in favour - but of a simple mechanism & 6 & 8 & 3 \\
\hline 2.5 & Ad valorem surcharge - in favour - transparency to the client & 3 & 3 & 3 \\
\hline 2.6 & Ad valorem surcharge - Rate - too high & 9 & 17 & 3 \\
\hline 2.7 & Ad valorem surcharge - Rate - too low & 3 & 4 & 2 \\
\hline 2.8 & Ad valorem surcharge - Risks on unit costs & 7 & 8 & 5 \\
\hline 2.9 & Ad valorem surcharge - transport optimisation - does not promote & 8 & 9 & 4 \\
\hline 2.10 & Ad valorem surcharge - transport optimisation - promotes & 3 & 6 & 2 \\
\hline 3.1 & Haulier/Shipper relationships - Creates conflicts & 1 & 1 & 0 \\
\hline 3.2 & Haulier/Shipper relationships - Creates negotiations & 13 & 39 & 7 \\
\hline 3.3 & Haulier/Shipper relationships - Generates tenders & 7 & 9 & 4 \\
\hline 3.4 & Haulier/Shipper relationships - impact in annual negotiations & 9 & 14 & 4 \\
\hline 4. & Investments issues (IT/OBU) & 15 & 51 & 7 \\
\hline 5. & Further questions/Uncertainty & 15 & 32 & 5 \\
\hline 6.1 & Principle of a tax - Agrees & 9 & 15 & 2 \\
\hline 6.2 & Principle of a tax - Only if it finances transport & 5 & 6 & 0 \\
\hline 6.3 & Principle of a tax - Only if it is paid by the final customer & 4 & 6 & 2 \\
\hline 7. & Alternative taxation - UK/DE Benchmark & 10 & 30 & 4 \\
\hline 8. & Sectorial aspect: scope of transport service vs scope of tax & 10 & 25 & 3 \\
\hline 9.1 & Test period - needed & 6 & 14 & 4 \\
\hline 9.2 & Test period - satisfactory & 1 & 1 & 0 \\
\hline 10.1 & Delocalisation risks - no & 4 & 7 & 1 \\
\hline 10.2 & Delocalisation risks - yes & 3 & 7 & 1 \\
\hline 11. & Difficult context - transport costs rising & 8 & 13 & 4 \\
\hline 12. & OBU Ownership by shipper & 8 & 9 & 4 \\
\hline 13. & Administrative costs of écotaxe & 8 & 8 & 4 \\
\hline 14. & Sub-contracting issues & 3 & 7 & 2 \\
\hline \multirow[t]{2}{*}{15.} & Tax avoidance - alternative routes are not possible & 6 & 6 & 4 \\
\hline & Total & 21 & 462 & 7 \\
\hline
\end{tabular}

\subsection{Data quality control}

To ensure that we had exhaustively covered all the topics, and that the code frequency was robust, two analyses were realised. The exhaustiveness is illustrated in the top graph of Fig. 4, where we can see that most of the topics were addressed at least once about half way through the interviews. The frequency analysis in the bottom graph of Fig. 4 shows that there is a good correlation between the code frequency (measured as the number of strings where a sub-topic is flagged) and the number of interviews where the code is identified at least once. The code at position $(5,20)$ is an exception due to the high code frequency in one particular interview and will be addressed in the results analysis. Data used for this chart are detailed in Table 8. The difference in the total number of codes between the two graphs is due to the fact that in the top graph we are counting codes at the topic level, and on the bottom graph, at the sub-topic level.

\section{Results and discussions}

Tables 8 and 9 show the result of the coding process: topics and sub-topics are presented with: the number of interviews where the (sub)topic appears (out of 21 interviews), the coding frequency and the number of road hauliers' interviews where the code appears 
(out of 7 interviews). Stakeholders from the road haulage sector were tracked as group because they were numerous enough to ensure anonymity, and also because, being at the core of this process, it was interesting to separate their interests from their clients' ones (shippers, intermodal companies and logistic companies).

\subsection{The main message: Competitive inequities}

The first topic in Table 8, "Competitive inequities" refers to issues concerning perceived inequities between competing companies. Results are detailed in Table 9. The competitive inequities issues were reported by both shippers and hauliers, who raised inequities due to three main reasons described hereafter.

\subsubsection{A surcharging scheme only applied to national, invoiced transport operations}

A particularity of the ad valorem surcharging system is that it could only be applied on "invoiced" transport operations in the French law, hence excluding from the scope of the surcharging scheme all own-account, in-house, transport operations (code 1.4) and those invoiced from another country (1.2). Therefore, companies with their own transport means (shippers mostly) felt they would not have the same legal support to negotiate the surcharge of the écotaxe cost to clients, compared to companies using an outsourced transport. An interviewee stated: “the outsourced transport has been favoured (...). Why the policymaker didn't think, (or) understand, that the haulier is not only the transport company? (...) as a consequence some companies which have their own vehicles are thinking to put them in a subsidiary in order to produce an invoice including the écotaxe, which could be presented to the customer". Another stakeholder from the road haulage sector indicated that "with the surcharging we questioned the ratio between our own fleet and subcontracted fleet, for delivery routing". Noticing that the surcharge would not be applied on foreign invoices, a shipper stated that "(since) the foreign haulier doesn't have the obligation to pass the cost, it undermines the competitiveness of French hauliers".

\subsubsection{Untaxed motorways: The écotaxe perceived as targeting local, short-distance businesses}

Some interviewees complained about the inequities generated in terms of distance to the Paris region, expressing it either in terms of local products versus imports (code 1.1), or in terms of short versus long distances (code 1.5). Two reasons were raised for this:

o Since motorways are not affected by the écotaxe, and many motorways provide direct access to Paris region, the écotaxe would create none or only a minor additional cost to importers or distant producers who can access Paris from abroad using exclusively motorways, but would more greatly impact local producers that approach the city using regional roads. The main ports serving the Paris region, Le Havre and Antwerp, are both connected to Paris via tolled motorways. A shipper stated that "a product imported from Spain or Italy will only start paying the écotaxe in Fontainebleau (approx.70 km from Paris) (...) this tax is an incentive to imports". And a haulier said that "this tax penalise French industry compared to the foreign one that export to France".

o And for those "distant producers" that don't use the motorway, they would be surcharged 5.2\%, whereas producers within Paris region would be surcharged $7 \%$. Among the 20 coded strings concerning foreign vs national production, 15 come from one single interview - this singularity was addressed as the code position $(5,20)$ when commenting on Fig. 4 in the methodology section. It does not change the overall importance of this issue that we have purposively grouped under the 'distance' factor, however it illustrates how much emphasis some shippers gave to this point.

\subsubsection{The surcharging scheme: The unachieved 'simplicity'}

The complexity of the surcharging system required management skills and administrative systems that interviewees felt only large hauliers would have already developed to an appropriate level, creating therefore a perceived bias in favour of large hauliers over the smaller ones (code 1.3). A transport federation stated that "écotaxe (...) will generate more administrative time (for invoicing). Only large hauliers will make it". A shipper federation said "Large hauliers know how to negotiate with shippers. The imbalance between the strong and the weak concerns the forwarder and the haulier (...) we create mechanisms to protect the hauliers but we have the opposite effect".

Two other minor equity issues were addressed. They concerned competition with smaller trucks, which would not pay the tax and the fear that government would not be able to adequately control foreign hauliers.

All transport federations took part in the design of the surcharging scheme. The inequity perception here is therefore predominantly an "inequity of the outcome" rather than an "inequity of policy design process". A federation stated that "the new minister was looking for a new (surcharging) tool. Early 2013 the surcharging mechanism is born. (We) have worked for (this)". Another road transport federation stated: "During the Grenelle (agreements) we worked to introduce the surcharging scheme (...) we were the only ones at the time". At the time of the interviews, the principle of a surcharging scheme was not questioned.

\subsection{The ad valorem surcharge: A revenue-neutral policy that backfired}

The "Ad valorem invoicing" topic was also extensively addressed (sometimes associated with the competitive inequities). The main issue, raised particularly by interviewees that were not hauliers (but also addressed by some hauliers), was that the average 


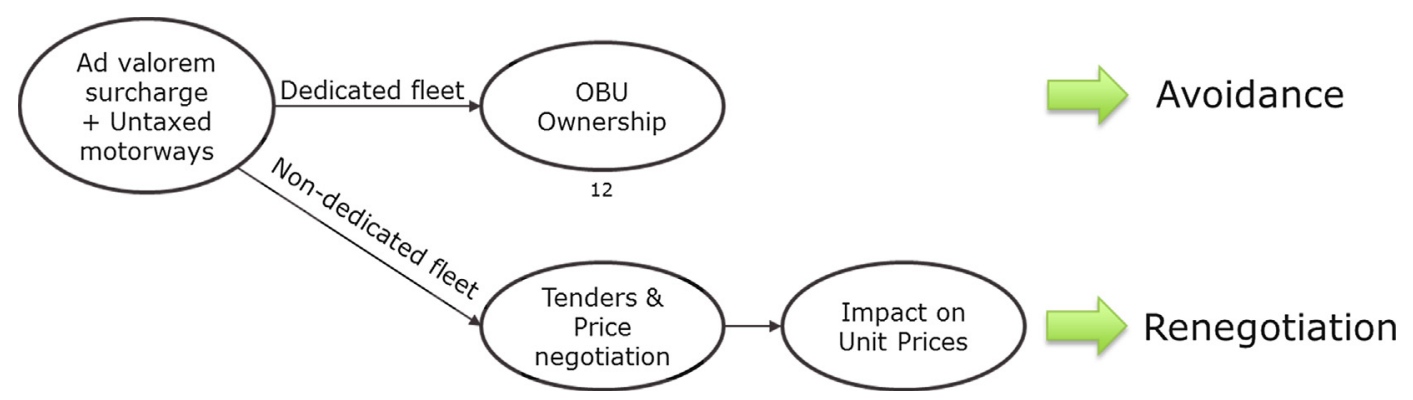

Fig. 5. Illustration of shippers' exit strategies.

surcharging rate to shippers was too high, when compared to the actual cost of the tax (codes 2.6 and 2.7).

The second issue was that ad valorem invoicing would somehow blur the "price-signal" message to the shipper, who sometimes takes the initiative of transport improvements. So neither transport optimisation (codes 2.9 and 2.10) nor modal transfer towards more use of eco-friendly rail or waterways alternatives (code 2.3) seemed really advantaged with this scheme. A shipper stated that "the écotaxe structure can incentivise the own-account transport to purchase Euro5 or Euro6 trucks. However the shipper has no interest in doing so when transport is outsourced". Concerning the modal transfer, it was stated that since multimodal transport is, in general, a profitable business in long distances only, the non-taxation of motorways (used for long distances) undermined the potential benefits of the écotaxe for the multimodal business. Moreover, since there is a dense network of motorways in the country, the haulier could drive untaxed to the shipper's facility almost until the last mile. Conversely, multimodal infrastructures are usually scarce and require a final road transport leg, potentially in taxed regional roads, surcharged at the regional level (7\% for Paris). As a shipper federation stated: "the leverage for modal transfer has no impact. The tax could even have the opposite effect".

The third issue was the perceived complexity of the surcharging scheme as a whole (codes 2.2 and 2.4), with surcharging rates depending on the point of collection and the point of delivery, and the consequent need to update information systems to collect this information. Despite all these drawbacks, when we look at codes 2.4 and 2.5 we see that a significant minority of interviewees supported the principle of a surcharging scheme, potentially redesigned.

The complexity of the surcharging scheme concerns also specific sectors (code 8) such as the multimodal transport, the express or Less than Truck Load transport, or local agriculture transport. For the multimodal transport, the price had to be split between the road section and modal section, in order to dissociate the portion of the service that would be taxed (and therefore surcharged) from the untaxed portion. The same applies to the express or Less than Truck Load services for which last mile collections and deliveries can be carried out with small, untaxed trucks. In these cases, as the écotaxe would apply only to a portion of the transport service, shippers would be required to split the invoice in order to have the surcharging scheme only applied to the taxed portion of the service. Local agriculture sector also found difficulties to apply the surcharging scheme as trucks usually drive only in limited areas, from the field to the nearby agri-industry plant, in remote sectors where there are almost no taxed roads. A road transport federation said, for instance that "(clients) refused to pay for the surcharging based on the fact that there are no taxed roads in the fields".

\section{Ecotaxe - Surcharge}
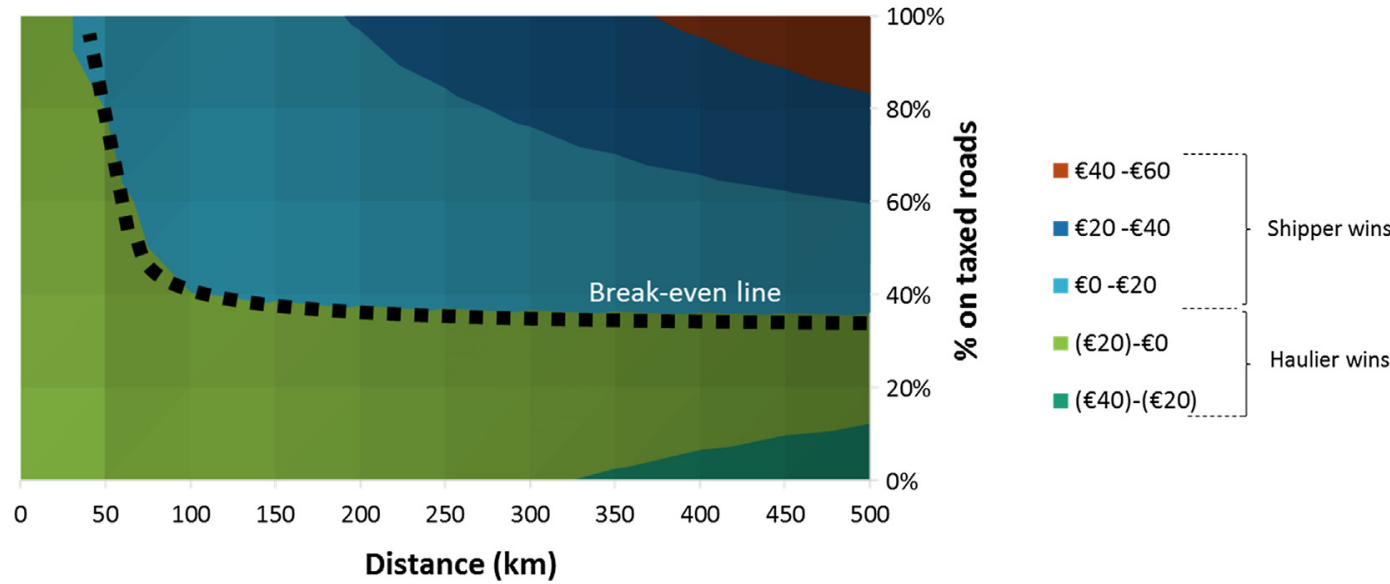

Fig. 6. Difference between the écotaxe and the surcharged value depending on distance and percentage of the journey on taxed sections. 
Also, interviewees reported uncertainties about sub-contracting issues between hauliers (code 14), relative to the inflationary risks resulting from the cumulative application of the surcharging system, as the same surcharge mechanism should be applied between a sub-contracted carrier and its main contractor.

\subsubsection{Exit strategies from the ad valorem surcharge - Unintended dysfunctional consequences}

As a consequence of this surcharging scheme, in 16 interviews out of 21 (including all hauliers), interviewees said that it impacted the Haulier/Shipper relationships (code 3). Although the écotaxe was not implemented yet, hauliers and shippers commercial relationships were disturbed. These negotiations were due in large part to the differences between the actual cost of the écotaxe for the haulier and the amount surchargeable to the client. Considering that the previous go-live date for the écotaxe was set to the first of January 2014, some shippers who felt disadvantaged by the surcharging system adopted two exit strategies:

- For shippers who had a dedicated fleet, the solution was to own themselves the OBUs and pay the écotaxe directly, thus avoiding the surcharging scheme (code 12). A shipper federation indicated for example that "the shipper, to avoid the 7\% surcharging rate, prefers to be the écotaxe payee by fitting himself his haulier's vehicles (with OBUs)"

- For the ones without a dedicated fleet, the solution was to launch tenders to obtain better prices (code 3.3) or re-negotiate prices (code 3.2). With the écotaxe postponement to the 1st of September 2014, and the overall uncertainty concerning the implementation process, many hauliers reported that these tenders were revised or cancelled, however it was more difficult to negotiate annual price increases (code 3.4).

Some interviewees feared that, with such a surcharging rate above the actual costs, hauliers would have, in future tenders, to reduce their unit prices below the actual operating costs, just to 'fit' with the legal surcharging rate (code: 2.8). Fig. 5 illustrates schematically the exit strategies used by shippers to avoid the perceived extra cost of the surcharging scheme.

Fig. 6 shows a simulation of the difference between the écotaxe (paid by the haulier) and the surcharged amount to the customer (via an ad valorem invoice), depending on the distance travelled and the percentage of the journey realised on tolled motorways. We chose a Euro III truck, using regional transport costs for March 2014 according to CNR values (see calculation details in Appendix C). A break-even (dotted) line in Fig. 6, splits the chart in two. In the bottom left section of the chart the result is negative, showing that the surcharged value is too high compared to the actual cost of the écotaxe, and in the top right section of the chart the result is positive, indicating that the surcharged value is not enough to pay the écotaxe. We can see that for hauliers using mostly taxed national roads, after a few kilometres the ad valorem rate would not recover the total cost of the écotaxe. Conversely, for hauliers using mostly motorways the ad valorem rate would be higher than the amount of écotaxe paid, explaining therefore the transport tenders and price negotiations.

\subsubsection{Why other surcharging schemes were a fallacious inspiration}

The interviews feedback shows that the promise of a "revenue-neutral" surcharging scheme for hauliers, made during the Grenelle agreements of 2007, was unrealistic. The scheme, carefully designed with the participation of shippers and transport federations, seemed initially simple, efficient and effective. It backfired. This is due, in our assessment, to the mandatory surcharging rates which, for the reasons previously stated, could not follow the real costs of the écotaxe. Furthermore, the presence of the surcharged amount on each invoice increased significantly the écotaxe administrative complexity.

Prior to the Grenelle agreements, a similar ad-valorem surcharging scheme had been successfully applied for the fuel surcharge, in 2006. Indeed as the underlying cost for fuel is relatively stable for a given transport service, independently of the road chosen, an ad valorem approach can be a good proxy of the actual fuel costs variations. This scheme is harder to apply when the underlying cost can vary significantly according to the roads selected (taxed or untaxed road sections). Furthermore, the fuel surcharge was used to protect against fuel price variations, and not to define its actual cost. Therefore, although the use of the fuel index was mandatory to assess its variations, the rate applied was negotiable, depending on the share of fuel cost estimated for a specific transport contract. In our case, with the purpose to protect hauliers, the ad-valorem rates were mandatory: consequently, when the applied rate generated a price increase higher than the écotaxe cost, shippers looked for exit strategies.

Another 'eco' surcharging scheme, the eco-participation for the recycling of electrical goods, had been established in the same period, in 2005. In this scheme the eco-participation appears at the bottom line of the invoice, but the underlying expense (recycling) is a collective one (among all distributors), carried out by an eco-organism, ensuring a similar cost among competing companies.

In our case, we think that the most effective system would have been indicative, not mandatory, mark-up rates provided by policymakers, to be used as a reference for negotiations. These rates should apply only once, at the time of the écotaxe implementation, and then disappear as part of the total transport costs in subsequent years. This would not ensure revenue-neutrality, but as previously stated, this promise was based on a fallacy, considering the structural variability of the écotaxe charges and the liquidity of the transport service market. 


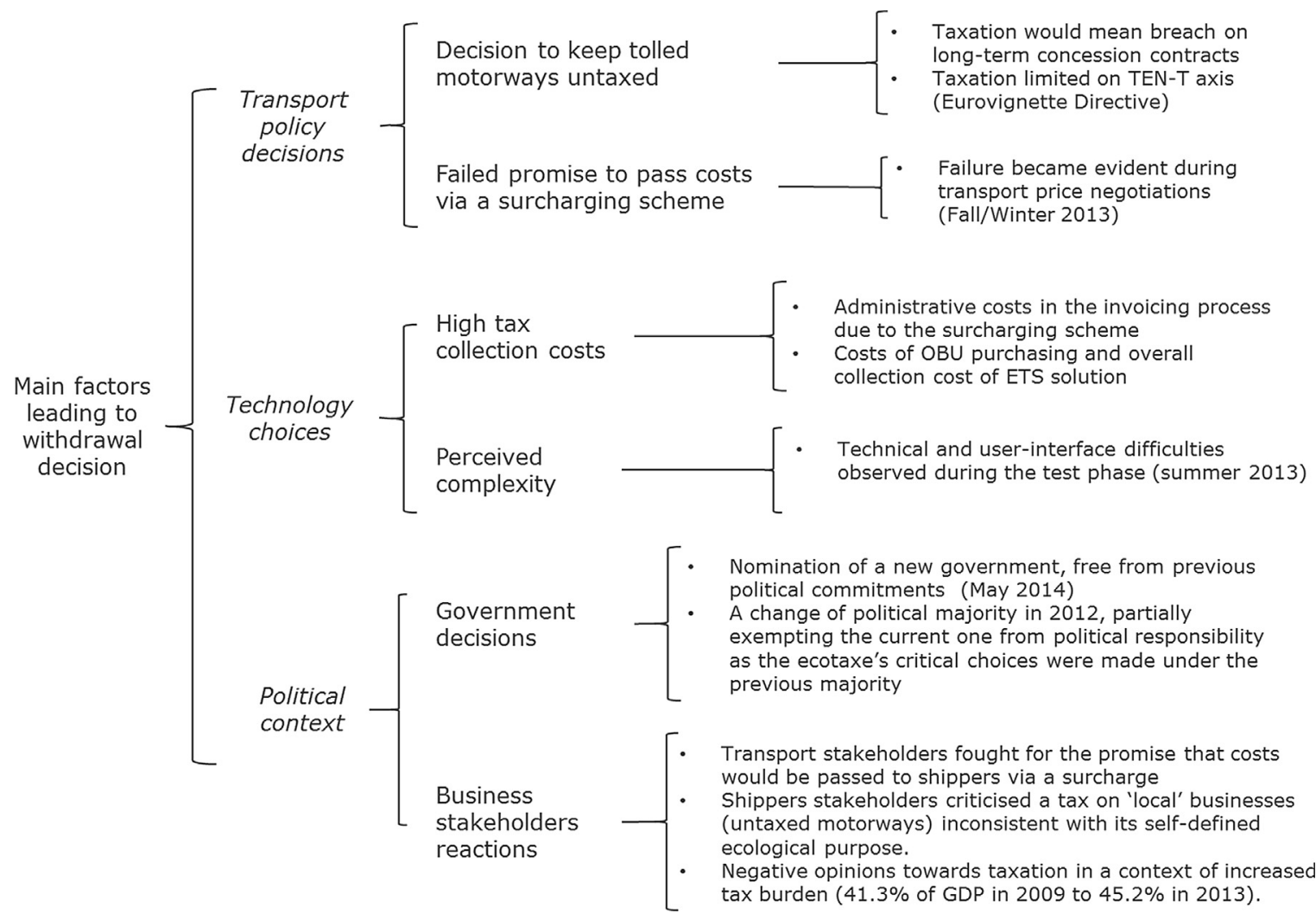

Fig. 7. Main factors leading to withdrawal decision.

\subsection{An 'eco' tax or 'infrastructure' tax? Misaligned perceptions of the tax purpose}

Surprisingly, considering the final outcome of the écotaxe, interviewees, including hauliers, were not advocating for its suppression at that stage. Actually, in 11 interviews (code 6, Table 8) they expressed that they understood the need of a tax, as long as revenues were earmarked to finance freight transport infrastructures and if this extra cost could be surcharged to the final client. These declarations obviously do not indicate a support for the écotaxe, but since none of them called explicitly for its cancellation, we can consider that the acceptance was already achieved among the panel of interviewees, possibly because we were interviewing them at a late stage of the implementation process. As Schade and Baum (2007, p. 47) state, "Normally people attempt to adapt to the new situation as soon as no real alternative is available". This feedback suggests that the "policy window" (Dudley, 2013) for the écotaxe was then not fully closed at the time. In short, many actors had already broadly accepted the principle of a taxation to finance transport infrastructure and expected that an improved écotaxe would be the solution implemented, taking their feedback into account.

Interestingly, we noted during the semantic analysis that interviewees used the French word "taxe" more frequently than "écotaxe", although interviewers only used the "écotaxe" term. This illustrates the misalignment between policymakers and business stakeholders concerning the 'problem identification' acceptability principle. Business stakeholders seemed to have accepted and perceived the écotaxe as tool to finance transport infrastructures, rather than as a green taxation instrument (code: 6.2). A shipper federation stated: "(we) were never against the écotaxe principle, since having quality infrastructures is important to France. The prerequisite is that the income must be pre-affected to infrastructure", another concluded: "In short, yes for the financing of infrastructure, but no for this mechanism (the surcharging scheme)". A stakeholder from the multimodal sector even said that "the abandon of the écotaxe would be an enormous waste".

The last labelling of the écotaxe, "Eco-Redevance kilometrique Poids-Lourds" - which lasted only a few months before its final cancellation - is a further indication that the perceptions of the policymakers and the stakeholders were still not fully aligned at the end of the process.

\subsection{Cost and complexity of the technology}

In 15 interviews, interviewees discussed 'cost efficiency' issues, complaining about the high cost of the system, either in terms of OBU purchase or investments already realised in the information systems in order to apply the surcharging scheme (code 4 in Table 8). This perception of a high cost, related to investments required to implement the system, was further exacerbated by the 
Framework Decisions
Selected stakeholders' perceptions (Coding process outcome)
Acceptability principles

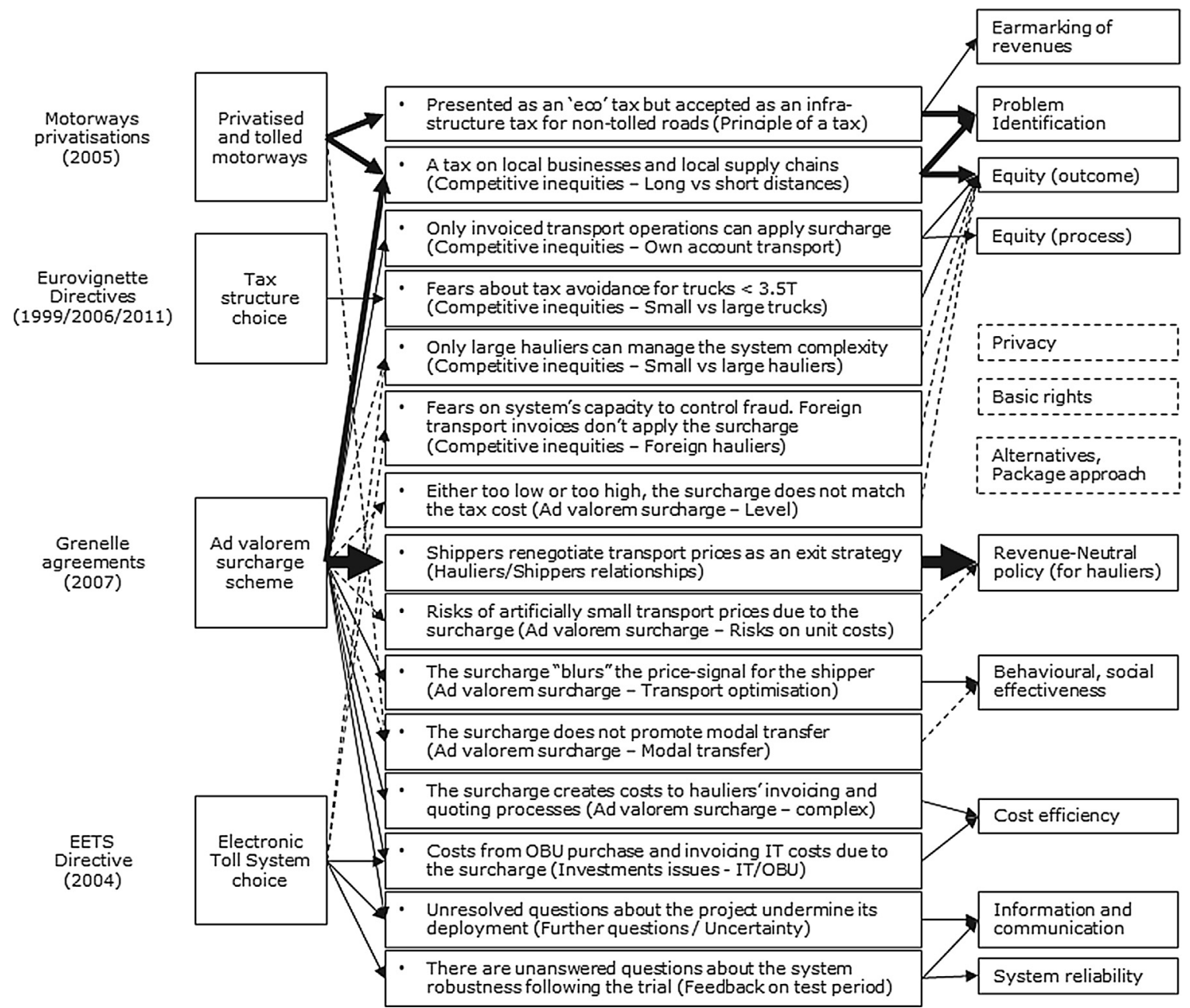

Fig. 8. Selected stakeholders' perceptions related to policy decisions, the legal framework and acceptability principles. Note: Links thickness represent the coding frequency.

anticipated costs related to the future management of the surcharging scheme, especially concerning the invoicing process (8 interviews, code 13 'administrative costs of écotaxe' in Table 8).

Also, many interviewees expressed discomfort with the uncertainty concerning the system and the implementation process overall (principles: system reliability and trust, information and communication). Furthermore, almost all interviewees providing a feedback about the écotaxe early implementation tests, carried out in 2013, indicated that this test period did not provide enough information about the system's functionality (codes 5 and 9 in Table 8; and codes 9.1, 9.2 in Table 9). This feedback seems to corroborate the idea that relatively 'low tech' approaches can be a good strategy for the freight transport sector, as promoted by Duncan and Graham (2013) and by McKinnon (2006a).

\subsection{Other minor issues}

Other issues were highlighted from interviews, such as discussions about alternative taxation systems (code 7) and the overall difficult context for hauliers (code 11). Some delocalisation risks for local businesses were also addressed but did not appear to be critical. These businesses, located within the region's border and subject to a 7\% surcharging rate to deliver in the Paris region instead of $5.2 \%$ if they were just outside, could envisage to relocate their activity outside the region (codes 10, 10.1, 10.2). Finally interviewees also commented that tax avoidance was difficult in Paris region as alternative untaxed routes were not available (code 15). 


\subsection{Why did the implementation failed? A synthesis of factors}

Figs. 7 and 8 summarise and synthesize the results of this work. Fig. 7 summarises the main factors including the factors which may have facilitated the government withdrawal decision. However, as indicated earlier, the écotaxe was built on the basis of a strong political consensus following the Grenelle agreements. Furthermore, it was known that project withdrawal would be an extremely costly decision. Therefore, the root causes of the écotaxe failure are to be found from the business stakeholders' reactions towards the above mentioned transport policy decisions.

Fig. 8 illustrates selected stakeholder perceptions (and their code topic) with two associations: on one side their root causes, i.e. decisions made at some point by policymakers and the legal framework; and on the other side the equity principles identified in the literature review. Links thickness represent the coding frequency of the code topic. Fig. 8 highlights the predominance of two transport policy decisions as critical to the project failure: the choice to keep motorways untaxed, and the surcharging scheme. The ETS choice raised questions and difficulties but was not seen as the main factor. Finally, the actual tax charging structure did not bring major sources of dissatisfaction.

\section{Conclusion}

The results show that the critical combination of two transport policy factors have contributed to undermine the 'equity' acceptance principle: a privatised, tolled, but untaxed motorways network and the ad valorem surcharging scheme.

A longitudinal look on the decision making process shows that many of the difficulties were rooted in decisions taken years ago: the motorways privatisation (2002-2006) and a surcharging scheme promised to hauliers at the Grenelle agreements (2007-2009). During the implementation phase, from 2010 onwards, policymakers could not provide a policy that could effectively navigate between these two constraints.

The study also shows the limitation of transferring ideas and policies considered successful elsewhere: copying 'successful policies' requires adaptation. For instance, the ad valorem surcharging that had been applied with success for the fuel surcharge, had a different function (to be used as an index) than for the écotaxe (to surcharge a cost). Also, the non-applicability of the écotaxe on tolled sections, created a strong sense of inequity about a taxation being predominantly applied to local businesses. The perceived favouring of longer distances in the proposed écotaxe regime also appeared incompatible with sustainable development, the concept used to promote it.

The exit strategies used by shippers to avoid the surcharging scheme served as a reminder that road transport is a commodity market with easy reallocation of resources. Distortions due to mandatory surcharging rates generated exit strategies through avoidance (OBU ownership) or negotiations/tenders, the latter generating inconsistent pricing for the actual transport service.

Furthermore, although technology was proven, we can see that ETS was perceived as an expensive and complex system, providing ground for the promotion of simple systems or "low tech" approaches.

The study shows also the importance of information and communication throughout the whole implementation process: acceptance of a tax as a principle does not ensure acceptance of its implementation, especially when policymakers fail to deliver promises, in our case a revenue-neutral mechanism for hauliers.

Finally, this case points to a problem that many policymakers could face in the future: since distance-based road taxation usually starts in main interurban roads or motorways, policymakers tempted to expand taxation towards secondary roads in order to increase revenue should consider that this option undermines the relevance of the "user-pays" principle, as there is less foreign transit traffic on these roads.

While the discussion about road taxation will certainly continue in the near future, we expect that the analysis above of the recent French experience can provide useful insights for any national policymaker considering introducing ETS systems.

\section{Funding}

This ex-post analysis did not receive any specific grant from funding agencies in the public, commercial, or not-for-profit sectors. The interviews scripts originate from a private funded project for the Ministère de l'Ecologie, du Développement Durable et de l'Energie (MEDDE).

\section{Acknowledgement}

The author acknowledges the participation of other team members in the original data collection process. The author is grateful for helpful comments from the anonymous reviewers. 


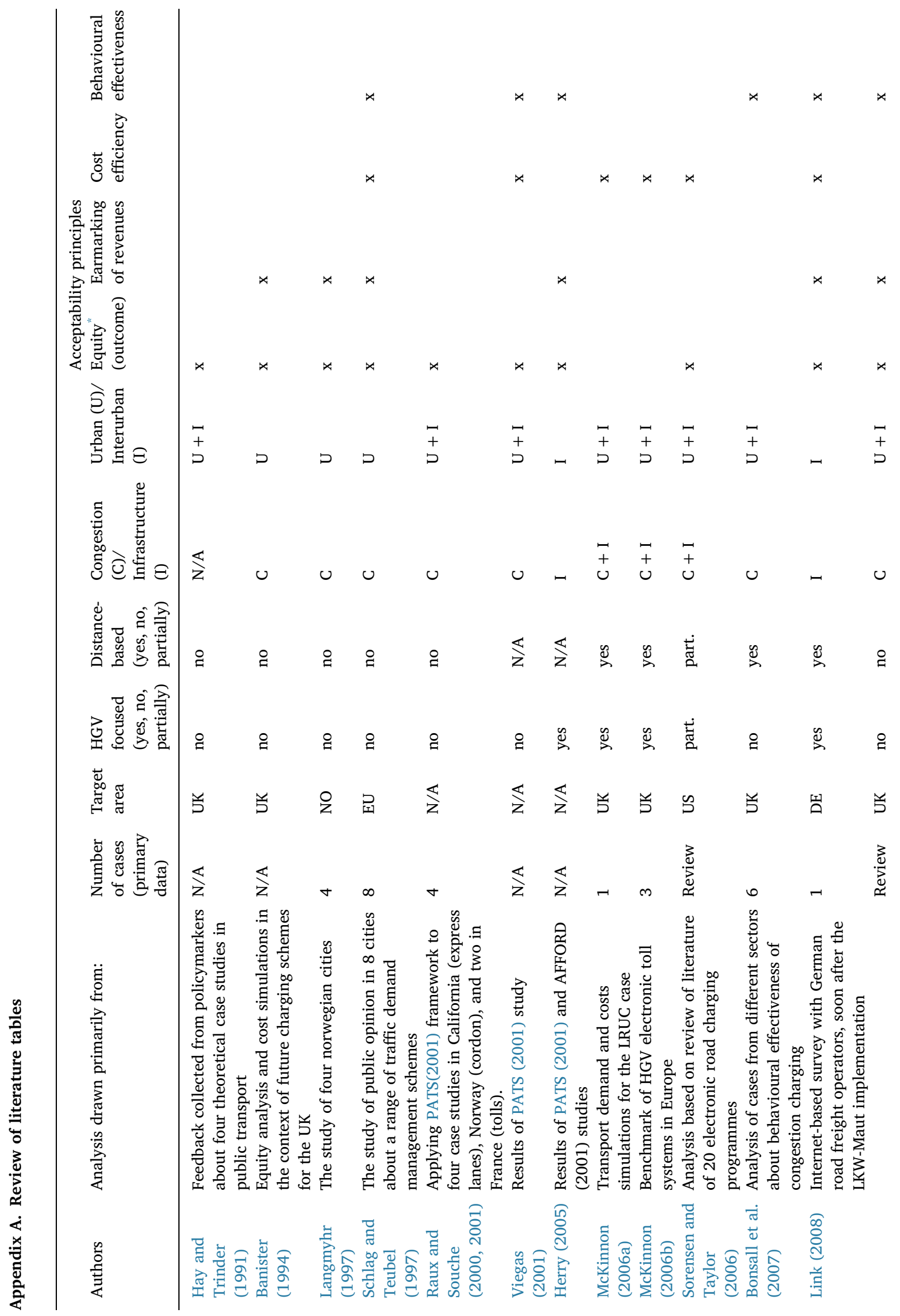




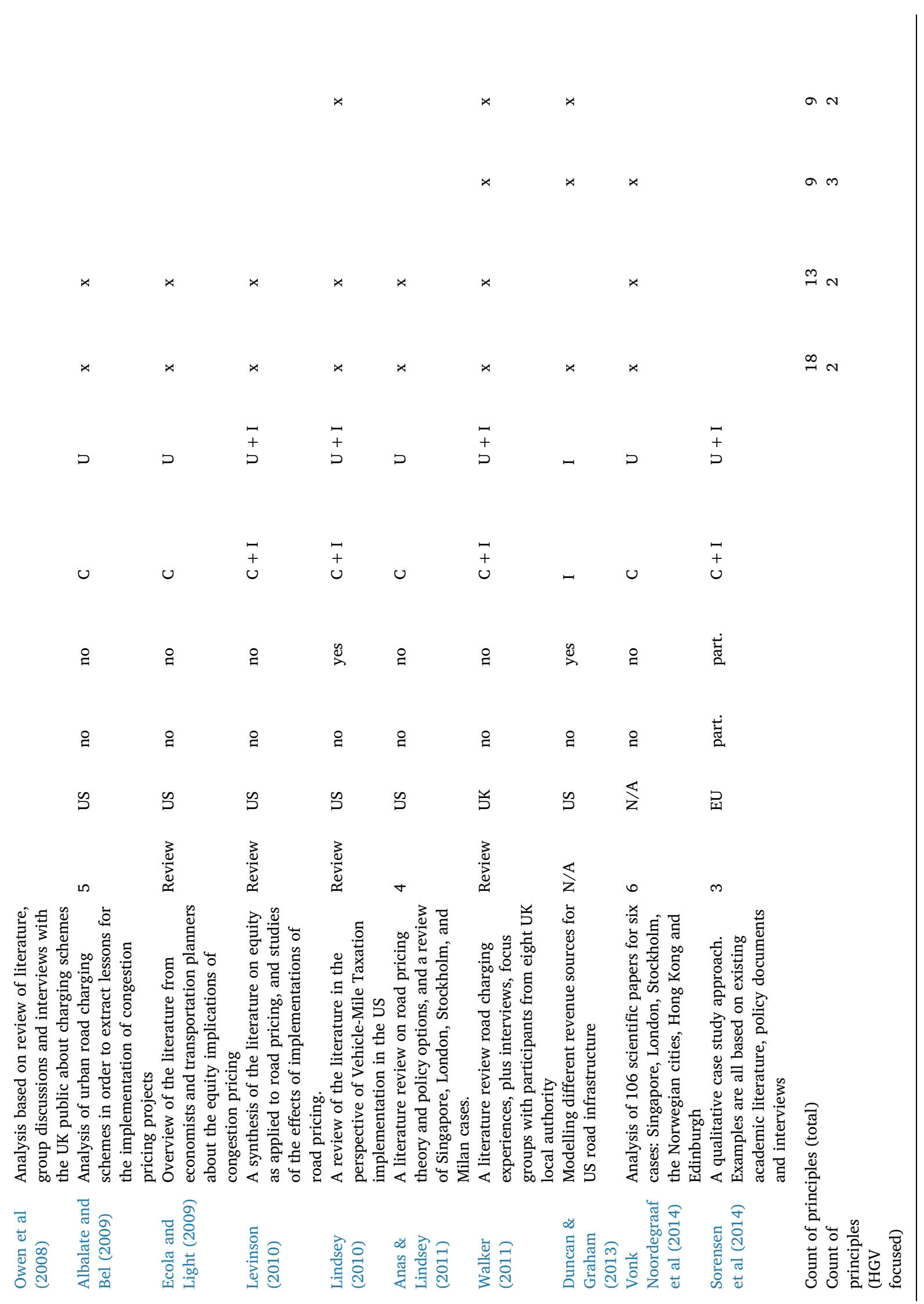




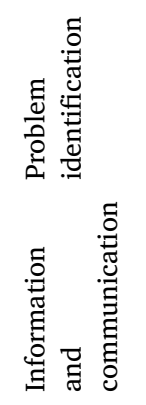

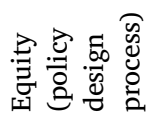

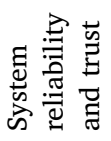

荡

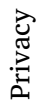

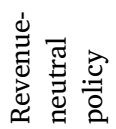

恶

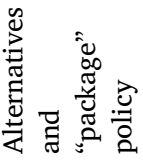

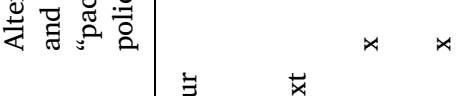

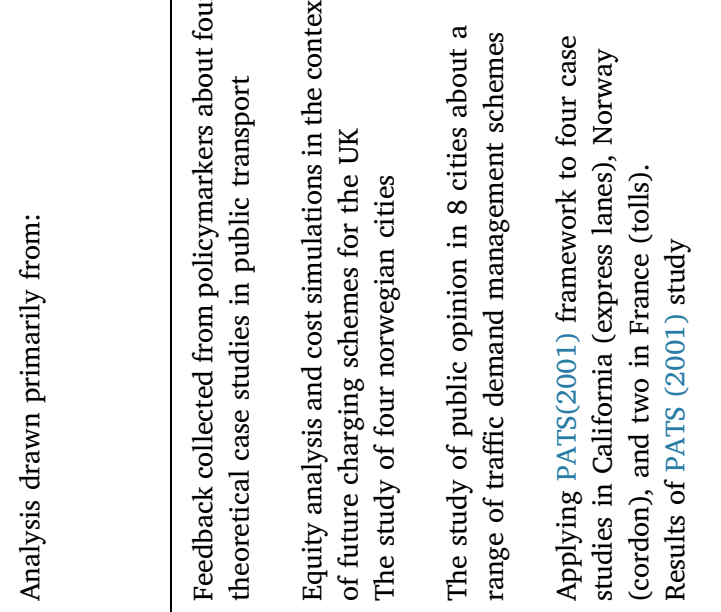

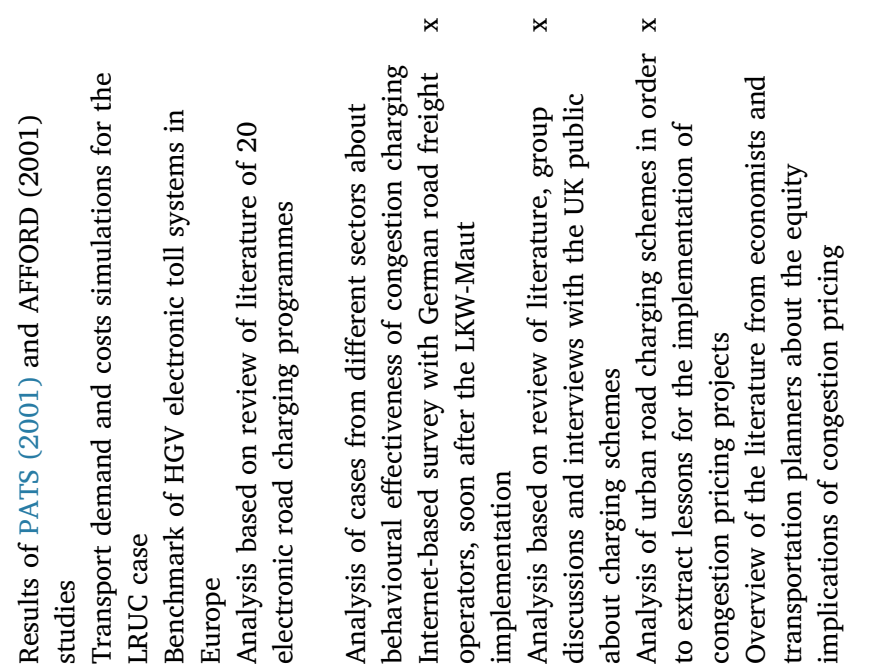

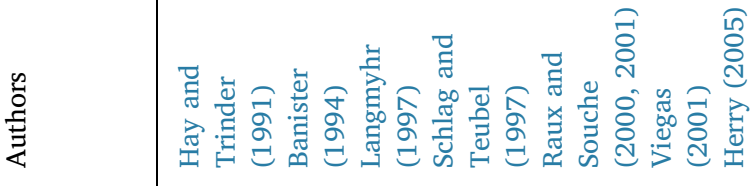

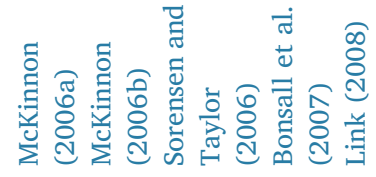

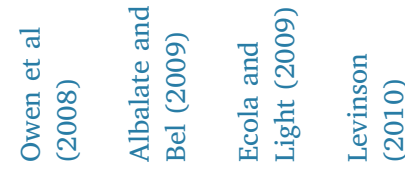




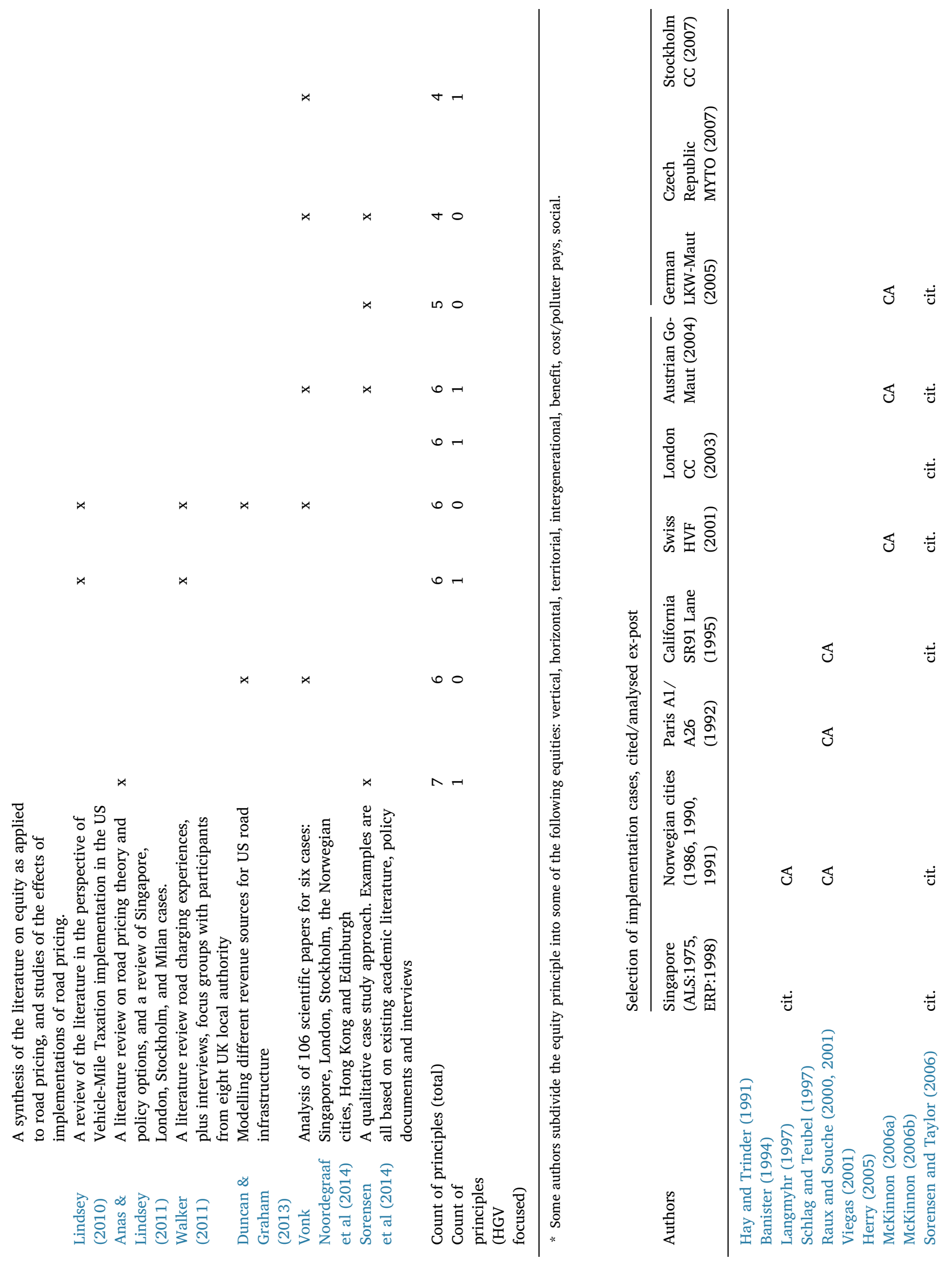




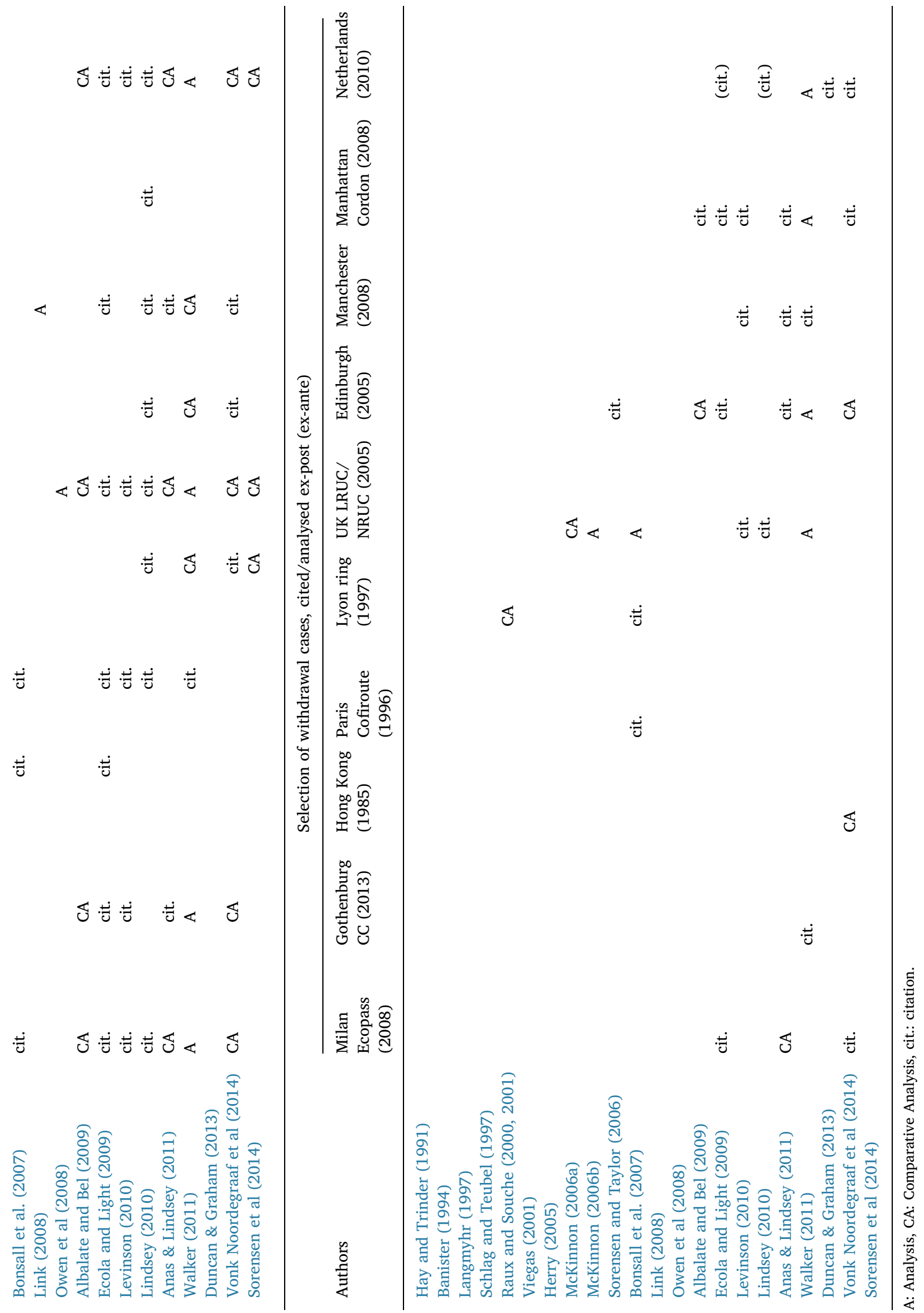




\section{Appendix B. Data processing}

The corpus was treated as a single text file with several strings (1023 non-empty strings in total). A string is a section of text terminating with an "end of line" symbol $(/ \mathrm{n})$. The resulting interviews transcripts had a total word count of 22,429 .

The corpus was then processed with the addition of "headers" before each interview in order to identify and process the interviews, and markers for the questions. We used standard form for text processing used in French tool Iramuteq (www.iramuteq.org). All remaining strings (which were not headers or questions) were identified as answers. The coding process was realised manually, string by string, over the 1023 non-empty strings.

We realised a simple count of word frequency, using Iramuteq to separate French active forms from supplementary forms. Also, some composed words were unified (such as "modal_transfer") and some plural forms brought to singular. The word count was realised with Python's Natural Language Toolkit. Except for these limited changes, no other text processing (such as lemmatisation) was carried out in order to keep the text as close as possible to its original content. Table 10 shows the corpus general profile.

As Table 11 shows, $58 \%$ of the text belongs to strings coded with a specific topic, $39 \%$ of the text belong to strings identified as

Table 10

Corpus word count per section.

\begin{tabular}{ll}
\hline Corpus section & Word count \\
\hline A - Answers & 20,696 \\
Q - Questions & 1649 \\
H - Headers & 84 \\
Total & 22,429 \\
\hline
\end{tabular}

Table 11

Coded sections.

\begin{tabular}{lll}
\hline Corpus section & Word count & $\%$ \\
\hline Specific topics & 11,916 & $58 \%$ \\
Generic topics & 8056 & $39 \%$ \\
Not coded & 724 & $3 \%$ \\
Total & 20,696 & $100 \%$ \\
\hline
\end{tabular}

'generic topics' and 3\% of the word count corresponded to strings that remained not coded. The 'generic topics' correspond to two codes: 'General presentation' and 'General cost issues'. "General presentation” corresponds to the presentation of the interviewees' organisation, its role, and their function within the organisation. "General costs issues" refers to topics related to the cost structure. These topics, although generic, are crucial to understand the context and the point of view of the interviewees. These codes had a frequency of 148 and 43, respectively, and were excluded from the analysis.

\section{Appendix C. Écotaxe value and the surcharged value}

The difference $\Delta$ between the écotaxe and the surcharged value is defined as follow:

$$
\Delta=\left(D_{\text {app }}+D \cdot \%_{\text {tax }}\right) \cdot E C-(P \cdot R R)
$$

where:

- $\mathrm{D}$ is the distance corresponding to the transport service ( $\mathrm{x}$-axis)

- $\mathrm{D}_{\mathrm{app}}=25.0 \mathrm{~km}$ is the approach distance (empty truck)

- $\%_{\text {tax }}$ is the percentage of the distance on taxed road, excluding approach (y-axis)

- $\mathrm{EC}=0.169 € / \mathrm{km}$ is the écotaxe rate applied

- $\mathrm{RR}$ is the surcharging rate, where we apply the regional rate for local transport (assumed here when $\mathrm{D} \leq 50 \mathrm{~km}$ ) and the interregional rate otherwise :

$$
R R=\left\{\begin{array}{l}
7.0 \%, D \leq 50 \mathrm{~km} \\
5.2 \%, D>50 \mathrm{~km}
\end{array}\right.
$$

- $\mathrm{P}$ is the price of the transport service 
The price of the transport is calculated using the following:

$$
C=\left(D+D_{\text {app }}\right) \cdot C_{\text {dist }}+\left(T_{\text {load }}+\frac{D+D_{\text {app }}}{\text { speed }}\right) \cdot\left(C_{\text {hour }}+\frac{C_{\text {day }}}{T_{\text {use }}}\right)
$$

where:

- $\mathrm{C}$ is the cost of the transport

- $\mathrm{m}=4.0 \%$ is the haulier's margin

- $\mathrm{T}_{\text {load }}=2.0 \mathrm{~h}$ is the time required to load and unload products

- speed $=61.1 \mathrm{~km} / \mathrm{h}$ is the average speed (CNR, March 2014)

- $\mathrm{T}_{\mathrm{use}}=9.6 \mathrm{~h} /$ day is the average truck utilisation per day in March 2014 (CNR, 2017)

- $\mathrm{C}_{\text {dist }}=0.51 € / \mathrm{km}$ is the distance-based unit cost in March 2014 (CNR, 2017)

- $\mathrm{C}_{\text {hour }}=18.74 € / \mathrm{h}$ is the hourly-based unit cost in March 2014 (CNR, 2017)

- $\mathrm{C}_{\mathrm{day}}=153.91 € / \mathrm{h}$ is the daily-based unit cost in March 2014 (CNR, 2017)

\section{References}

4icom, Steer Davies Gleave, 2015. Study on state of the art of electronic road tolling. MOVE/D3/2014-259”, October 2015, last accessed: 15/09/2017 available at: < https://ec.europa.eu/transport/sites/transport/files/modes/road/road_charging/doc/study-electronic-road-tolling.pdf > .

Albalate, D., Bel, G., 2009. What local policy makers should know about urban road charging: lessons from worldwide experience. Public Admin. Rev. 69 (5), $962-975$.

Anas, A., Lindsey R., 2011. Reducing urban road transportation externalities: road pricing in theory and in practice. Review of Environmental Economics and Policy, Vol. 5 (1), winter 2011, pp. 66-88.

ASECAP - Association Européenne des Concessionnaires d'Autoroutes et d'Ouvrages à Péages, 2014. Evaluation and future of road toll concessions. ASECAP Report, last accessed 23/02/2018, available at: < http://www.asecap.com/images/documents/CONCESSIONSSTUDY/concessionsstudyfullreport.pdf > .

Assemblée Nationale, 2008. Projet de loi de finances pour 2009. enregistré à la Présidence de l'Assemblée nationale le 26 septembre 2008. Last accessed: 07/07/2017, available at: http://www.assemblee-nationale.fr/13/pdf/projets/pl1127.pdf.

Assemblée Nationale, 2011. Rapport d'information sur la mise en place de la taxe Poids Lourds. French National Assembly Report, No 3782, 4th October 2011, last accessed 28/06/2017, available at: < http://www.assemblee-nationale.fr/13/rap-info/i3782.asp > .

Assemblée Nationale, 2014a. Rapport d'information déposé par la mission d'information sur l'écotaxe poids lourds. presented by M. Jean-Paul Changuet, Deputy, 14th of May 2014. Last accessed 29/06/2017, Available at: < http://www.assemblee-nationale.fr/14/pdf/rap-info/i1937.pdf > .

Assemblée Nationale, 2014b. Rapport d'information déposé par la mission d'information sur la place des autoroutes dans les infrastructures de transport au nom de la commission du developpement durable et de l'ameagement du territoire. Presented by Bertrand Pancher, President, and Jean-Paul Chanteguet, Deputy, 17th of December 2014, last accessed 29/06/2017, available at: < http://www.assemblee-nationale.fr/14/pdf/rap-info/i2476.pdf > .

Assemblée Nationale, 2014c. Amendement no. 19 du projet de loi de finance 2014. 17 novembre 2014, last accessed: 07/07/2017, available at: < http://www. assemblee-nationale.fr/14/amendements/2353/AN/19.pdf $>$.

Assemblée Nationale, 2016. Amendement no. II-808 du projet de loi de finance 2017. 13 novembre, 2013, last accessed: 07/07/2017, available at: < http://www. assemblee-nationale.fr/14/amendements/4061C/AN/808.pdf > .

Banister, D., 1994. Equity and Acceptability Question. In Internalising the Social Costs of Transport, OECD report, chapter 6, last accessed 25/07/2017, available at: < http://citeseerx.ist.psu.edu/viewdoc/download?doi $=10.1 .1 .196 .6471 \& \mathrm{rep}=$ rep $1 \&$ type $=$ pdf $>$.

Bonsall, P., Shires, J., Maule, J., Matthews, B., Beale, J., 2007. Responses to complex pricing signals: theory, evidence and implications for road pricing. Transport. Res. A 41, 672-683.

CEDD, Conseil économique pour le développement durable, 2013. Comment tarifer l'usage des routes au juste prix ? Leçons de l'écotaxe PL”, Synthèse no. 20, Décembre 2013, last accessed: 06/07/2017, available at: < https://www.ecologique-solidaire.gouv.fr/sites/default/files/CEDD\%20-\%20S\%20020.pdf > .

CESifo, 2014. DICE Report 3/2014. September issue, last accessed 23/02/2018, available at: < https://www.cesifo-group.de/ifoHome/facts/DICE/Infrastructure/ Transportation/Road-Transport/Road-User-Charging-European-Union/fileBinary/Road-User-Charging-in-the-European-Union_dicereport314-db2.pdf > .

Chilroleu-Assouline, M., 2015. La fiscalité environnementale en France peut-elle devenir réellement écologique ? Etat des lieux et conditions d'acceptabilité. Revue de l'OFCE, 2015/3, no. 139, pp. 129-165.

CNR, 2017. Comité National Routier. Référentiel Prix de Revient. last accessed: 21/09/2017, available at: < http://www.cnr.fr/index.php/fr/Indices-Statistiques/ Regional-40T/Referentiel-prix-de-revient $>$.

Conseil d'Etat, 2016. Association Alsace Nature. Nos 399965, 399966, CE, 5 décembre 2016, last accessed 28/06/2017, available at: < http://www.conseil-etat.fr/ Decisions-Avis-Publications/Decisions/Selection-des-decisions-faisant-l-objet-d-une-communication-particuliere/CE-5-decembre-2016-Association-AlsaceNature $>$.

Cour des comptes, 2017. L'écotaxe poids lourds, un échec stratégique, un abandon coûteux. in Rapport public annuel 2017, last accessed 08/03/2018, available at: < https://www.ccomptes.fr/fr/publications/le-rapport-public-annuel-2017 > .

Cour des comptes, 2013. Les relations entre l'Etat et les sociétés concessionnaires d'autoroutes", in Communication à la commission des finances de l'Assemblée Nationale, July 2013, last accessed 08/03/2018, available at: < https://www.ccomptes.fr/fr/publications/les-relations-entre-letat-et-les-societesconcessionnaires-dautoroutes $>$.

DfT - Department for Transport, 2017. Reforming the HGV road user levy: call for evidence. November 2017, London: DfT.

Doll, C., Schaffer, A., 2007. Economic impact of the introduction of the German HGV toll system. Transport Policy 14 (1), $49-58$.

Dudley, G., 2013. Why do ideas succeed and fail over time? The role of narratives in policy windows and the case of the London congestion charge. J. Eur. Public Policy 20 (8), 1139-1156.

Duncan, D., Graham, J., 2013. Road user fees instead of fuel taxes: the quest for political acceptability. Public Admin. Rev. 73 (3), $415-426$.

Dyrhauge, H., 2014. The road to environmental policy integration is paved with obstacles: the intra- and inter-organizational conflicts in EU transport decisionmaking. J. Common Mark. Stud. 52 (5), 985-1001.

Ecola, L., Light, T., 2009. Equity and Congestion Pricing. A Review of the Evidence. Technical Report, Transportation, Space, and Technology (TST) Program, Rand Corporation.

European Commission, 1995. Towards a Fair and Efficient Pricing in Transport. Green Paper, last accessed 04/07/2017, available at: < http://europa.eu/documents/ comm/green_papers/pdf/com95_691_en.pdf > .

European Commission, 1998. Fair Payment for Infrastructure Use: A phased approach to a common transport infrastructure charging framework in the EU. White Paper, last accessed 04/07/2017, available at: < http://edz.bib.uni-mannheim.de/www-edz/pdf/kom/weissbuch/kom-1998-0466-en.pdf > .

European Commission, 2001. European transport policy for 2010: time to decide. White Paper, last accessed 04/07/2017, available at: < https://ec.europa.eu/ transport/sites/transport/files/themes/strategies/doc/2001_white_paper/lb_com_2001_0370_en.pdf > . 
European Commission, 2011. Roadmap to a single European transport area: towards a competitive and resource-efficient transport system. White paper, last accessed 04/07/2017, available at: < http://eur-lex.europa.eu/legal-content/EN/TXT/PDF/?uri=CELEX:52011DC0144\&from =EN > .

European Commission, 2013. Commission staff working document - Ex-post evaluation of Directive 1999/62/EC, as amended, on the charging of heavy goods vehicles for the use of certain infrastructures. 10th January 2013, last accessed 30/06/2017, available at: < https://ec.europa.eu/transport/sites/transport/files/modes/ road/road_charging/doc/swd\%282013\%291.pdf > .

European Commission, 2017. Impact assessment accompanying the document: proposal for amending Directive 1999/62/EC on the charging of heavy goods vehicles. Commission staff working document, Part 2, last accessed: 06/03/2018, available at: < https://ec.europa.eu/transport/sites/transport/files/swd20170180-iapart2-eurovignette-infrastructure.pdf $>$.

European Union, 1999. Directive 1999/62/EC of the European Parliament and of the Council of 17 June 1999 on the charging of heavy goods vehicles for the use of certain infrastructures. last accessed 04/07/2017, available at: < http://eur-lex.europa.eu/LexUriServ/LexUriServ.do?uri= OJ:L:1999:187:0042:0050:EN:PDF >

European Union, 2004. Directive 2004/52/EC of the European Parliament and of the Council of 29 April 2004 on the interoperability of electronic road toll systems in the Community. Available at: < http://eur-lex.europa.eu/legal-content/EN/TXT/PDF/?uri=CELEX:32004L0052 > .

European Union, 2011. Directive 2011/76/EU of the European Parliament and of the Council of 27 September 2011 amending Directive 1999/62/EC on the charging of heavy goods vehicles for the use of certain infrastructures. Available at: < http://eur-lex.europa.eu/legal-content/EN/TXT/PDF/?uri=CELEX:32011L0076 >

Guarnieri, P., 2012. French eco-tax collection system towards EETS. In: Proceedings of the 19th Intelligent Transport Systems World Congress, ITS, Vienna, 22-26 October 2012 (available at: < https://trid.trb.org/view.aspx?id =1263475 > .

Harnay, P., 2012. La fiscalité carbone en France: un échec face à la Suède? Le cas des transports routiers de merchandise. Les Cahiers Scientifiques du Transport, AFITL, 2012, pp .35-62.

Harnay, P.V., Rème, P., 2012. Carbon taxation in France: a failure compared with experience elsewhere in Europe? The case of road freight transport. Eur. Transp. Res. Rev. 4 (4), 201-215.

Hay, A., Trinder, E., 1991. Concepts of equity, fairness, and justice expressed by local transport policymarkers. Environ. Plan. C 9 (4), $453-465$.

Herry, M., 2005. "The acceptability dimension”, in interurban road charging for truck in Europe. Res. Transport. Econ. 11, 75-88.

Hylén, B., Kauppila, J., Chong, E., 2013. Road Haulage Charges And Taxes, Summary analysis and data tables 1998-2012. International Transport Forum Discussion Paper, OECD; August 2013.

Journal Officiel, 2012. Décret no. 2012-670 du 4 mai 2012 relatif aux modalités de majoration du prix du transport liée à l'instauration de la taxe alsacienne et de la taxe nationale sur les véhicules de transport de marchandises. last accessed 29/06/2017, available at: < https://www.legifrance.gouv.fr/eli/decret/2012/5/4/ TRAT1205999D/jo > .

Journal Officiel, 2009. Loi no. 2009-967 du 3 août 2009 de programmation relative à la mise en œuvre du Grenelle de l'environnement. article 11, last accessed 29/06/ 2017, available at: < https://www.legifrance.gouv.fr/affichTexte.do?cidTexte = JORFTEXT000020949548\&categorieLien =id > .

Journal Officiel, 2006. LOI no. 2006-10 du 5 janvier 2006 relative à la sécurité et au développement des transports. article 23, last accessed 12/07/2017, available at: < https://www.legifrance.gouv.fr/affichTexte.do?cidTexte = JORFTEXT000000456019\&categorieLien =id > .

Kossak, A., 2012. HGV Road Pricing in Europe: History, Status, Challenges, Perspectives. Goods Movement and Mobility Pricing Forum, Transport Futures, Toronto, Ontario, May 31, 2012, last accessed 06/03/2018, available at: < http://www.transportfutures.ca/sites/default/files/TF_Goods_-_Andreas_Kossak_0.pdf > .

Langmyhr, T., 1997. Managing equity. The case of road pricing. Transport Policy 4 (1), 25-39.

Liechti, M., Renshaw, N., 2006. A price worth paying: a guide to the new EU rules for road tolls for lorries. T\&E 06/1, European Federation for Transport and Environment, Brussels: T\&E.

Levinson, D., 2010. Equity effects of road pricing: a review. Transport Rev. 30 (1), 33-57.

Lindsey, R., 2010. Reforming road user charges: a research challenge for regional science. J. Reg. Sci. 50 (1), $471-492$.

Link, H., 2008. Acceptability of the German charging scheme for heavy goods vehicles: empirical evidence from a freight company survey. Transp. Rev. 28 (2), $141-158$.

McKinnon, A.C., 2006a. Government plans for lorry road-user charging in the UK: a critique and an alternative. Transp. Policy 13, $204-2016$.

McKinnon, A., 2006b. A review of European truck tolling schemes and assessment of their possible impact on logistics systems. Int. J. Logist. Res. Appl. 9 (3), 191-205.

Mertner, J., Skov, M.K., 2005. "Harmonisation and interoperability of national tolling schemes", in Interurban Road Charging for Truck in Europe. Res. Transport. Econ. 11, 133-151.

Nowacki, G., Niedzicka A., 2009. Some problems with the European Electronic Toll Service Interoperability. In: Proceedings of the 9th International Conference "Reliability and Statistics in Transportation and Communication", (RelStat'09), 21-24 October 2009, Riga, Latvia, p. 185-192. ISBN 978-9984-818-21-4.

Ollivier-Trigalo, M., 2013. L'instauration d'une écotaxe poids-lourds en France: endurance technico-économique et impulsions politiques. Développement durable et territoires 4 (3), 2013.

Ollivier-Trigalo, M., 2012. L'instauration d'une écotaxe sur les poids-lourds en France: la fabrique d'une politique routière?. Rapport PREDIT 4, Groupe opérationnel no. 6 "Politiques de transport", Janvier 2012.

Owen, R., Sweeting, A., Clegg, S., Musselwhite, C., Lyons, G., 2008. Public acceptability of road pricing. Technical Report. Department for Transport, London, last accessed 27/07/2017, available at: < http://eprints.uwe.ac.uk/10351/1/10351.pdf > .

PATS - Pricing Acceptability in the Transport System, 2001. Recommendation on Transport Pricing Strategies. Report for the EU Transport Research 4th FP, Urban Transport, Project Coordinator: TIS.PT, Consultores em Transportes Inovação e Sistemas a.c.e, Lisbon, Portugal.

Rapp, M., Hansen, P.S., 2007. Evaluation of different scenarios of a HGV charging system in Denmark. 6th European Congress and Exhibition on Intelligent Transport Systems, Aalborg, 2007. last accessed 06/03/2018, available at: < https://www.rapp.ch/wAssets-de/docs/trans/fachartikel-referate/2007/dokumente/itscongress-aalborg/hgv_charging_denmark_rapp_skrumsager_final.pdf $>$.

Raux, C., Souche, S., 2000. Acceptability factors to transport policy changes. European Transport Conference, 11-13 September 2000, Cambridge, UK.

Raux, C., Souche, S., 2001. L'acceptabilité des changements tarifaires dans le secteur des transports : comment concilier efficacité et équité ?. Revue d’Économie Régionale \& Urbaine 2001/4 (octobre), pp. 539-558. doi: 10.3917/reru.014.0539.

RDW, 2012. Road pricing in Europe. 2nd version, April 2012. Zoetermeer: RDW.

Schade, J., Baum, M., 2007. Reactance or acceptance? Reactions towards the introduction of road pricing. Transport. Res. A 41, $41-48$.

Schlag, B., Teubel, U., 1997. Public acceptability of transport pricing. Dresden University of Technology, Traffic and Transportation Psychology, last accessed 25/07/ 2017, available at: < http://www.cleanairinstitute.org/cops/bd/file/gdt/82-public-acceptability-of-transport-pricing.pdf > .

Sénat, 2013. Avis présenté au nom de la commission des finances sur le projet de loi portant diverses dispositions en matière d'infrastructures et de services de transports", by Mme Marie-Hélène Des Esgaulx, Senator, 5th February 2013, last accessed 29/06/2017, available at: < https://www.senat.fr/rap/a12-334/a123341.pdf > .

Sorensen, C.H., Isaksson, K., Macmillen, J., Akerman, J., 2014. Strategies to manage barriers in policy formation and implementation of road pricing packages. Transport. Res. Part A 60, 40-52.

Sorensen, P.A., Taylor, B.B., 2006. Innovation in road finance: examining the growth in electronic tolling. Public Works Manage. Policy 11 (2), $110-125$.

Vega, A., Evers, N., 2016. Implications of the UK HGV road user charge for Irish export freight transport stakeholders - a qualitative study. Case Stud. Transport Policy 4, 208-217.

Viegas, J., 2005. Introduction: paying for road use. In Research in Transport Eonomics, Special Edition on Interurban Road Charging for Trucks in Europe, Volume 11, 1st ed.. Editors: Jose Viegas, ISBN: 9780080456669 (eBook).

Viegas, J., 2001. Making urban road pricing acceptable and effective: searching for quality and equity in urban mobility. Transp. Policy 8, $289-294$.

Vonk Noordegraaf, D., Annema, J.A., van Wee, B., 2014. Policy implementation lessons from six road pricing cases. Transport. Res. Part A 59, $172-191$.

Walker, J., 2011. The acceptability of road pricing. RAC Foundation, May 2011. 